\title{
Genome-wide evolutionary response of European oaks since the Little Ice Age
}

Dounia Saleh $^{\mathrm{a}^{*}}$, Jun Chen ${ }^{\mathrm{b} *}$, Jean-Charles Lepléa ${ }^{\mathrm{a}}$, Thibault Leroy ${ }^{\mathrm{c}}$, Laura Truffaut ${ }^{\mathrm{a}}$, Benjamin Dencausse $^{\mathrm{a}}$, Céline Lalanne ${ }^{\mathrm{a}}$, Karine Labadie ${ }^{\mathrm{d}}$, Isabelle Lesur ${ }^{\mathrm{e}}$, Didier Bert ${ }^{\mathrm{a}}$, Frédéric Lagane ${ }^{\mathrm{a}}$, François Morneau ${ }^{\mathrm{f}, 1}$, Jean-Marc Aury ${ }^{\mathrm{g}}$, Christophe Plomion ${ }^{\mathrm{a}}$, Martin Lascoux ${ }^{\mathrm{h}}$, Antoine Kremer $^{\mathrm{a}, 2}$

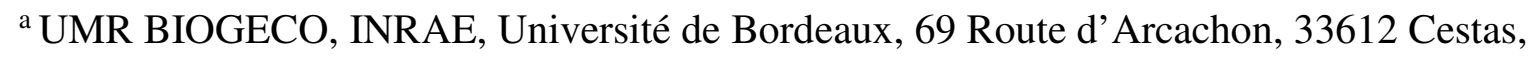
France

${ }^{\mathrm{b}}$ College of Life Sciences, Zhejiang University, Hangzhou, Zhejiang 310058, China

${ }^{\mathrm{c}}$ Department of Botany \& Biodiversity Research, University of Vienna, Vienna, Austria

${ }^{\mathrm{d}}$ Genoscope, Institut de Biologie François Jacob, Commissariat à l'énergie atomique (CEA), Université de Paris-Saclay, 2 rue Gaston Crémieux, 91057 Evry, France

${ }^{\mathrm{e}}$ Helix Venture, 33700 Merignac France

${ }^{\mathrm{f}}$ Département Recherche Développement Innovation, Office National des Forêts, 100

Boulevard de la Salle, 45760 Boigny-Sur-Bionne, France

g Génomique Métabolique, Genoscope, Institut François Jacob, CEA, CNRS, Univ Evry,

Université Paris-Saclay, 91057 Evry, France

${ }^{\mathrm{h}}$ Department of Ecology and Genetics, Evolutionary Biology Centre, Uppsala University, 75236 Uppsala, Sweden

*: These two authors contributed equally to the work

1: Present address: Service de l'Information Statistique Forestière et Environnementale, Institut National de l'Information géographique et Forestière, Château des Barres, 45290 Nogent sur Vernisson France

2: Corresponding author: antoine.kremer@inrae.fr

Short running title: Genome-wide microevolution in oaks

Keywords: Linked selection, evolution, Quercus petraea, Little Ice Age 


\begin{abstract}
The pace of tree microevolution during Anthropocene warming is largely unknown. We used a retrospective approach to monitor genomic changes in oak trees since the Little Ice Age (LIA). Allelic frequency changes were assessed from whole-genome pooled sequences for four agestructured cohorts of sessile oak (Quercus petraea) dating back to 1680, in each of three different oak forests in France. The genetic covariances of allelic frequency changes increased between successive time periods, highlighting genome-wide effects of linked selection. We found imprints of convergent linked selection in the three forests during the late LIA, and a shift of selection during more recent time periods. The changes in allelic covariances within and between forests mirrored the documented changes in the occurrence of extreme events (droughts and frosts) over the last three hundred years. The genomic regions with the highest covariances were enriched in genes involved in plant responses to pathogens and abiotic stresses (temperature and drought). These responses are consistent with the reported sequence of frost (or drought) and disease damage ultimately leading to the oak dieback after extreme events. Our results therefore provide evidence of selection operating on long-lived species during recent climatic changes.
\end{abstract}




\section{INTRODUCTION}

Our ability to forecast the response of species to climate change is limited by our lack of knowledge about the pace of adaptive evolution, particularly in long-lived species, such as trees. Standing tree populations already had to survive important environmental changes during their lifetime and these environmental challenges likely triggered significant evolutionary changes, though the magnitude of tree adaptive response remains to be quantified. More specifically, multicentennial trees in the Northern Hemisphere that are old enough to have experienced the transition from the cold Little Ice Age (LIA, 1450-1850) to the warm Anthropocene (1850-today) (Luterbacher et al. 2004; Corona et al. 2010; Luterbacher et al. 2016; Anchukaitis et al. 2017) offer a unique opportunity to assess the extent of genome-wide response to this extreme and well described environmental challenge. The LIA (Tkachuck 1983) was a cold period characterized by climatic extremes such as long and harsh winters, but also severe droughts that led to plagues, famines and ultimately revolutions (Pfister 1984; Fagan 2002; Parker 2013 ). The consequences of the LIA for plants are best illustrated by the recurrent poor crop harvests (Le Roy Ladurie 2004, 2006). Evidence of the impact of the LIA on forest trees is provided by comparisons of tree ring sizes and historical temperature records (Carrer \& Urbinati 2006; Edouard et al. 2009). According to inferences concerning past forest tree dynamics from subfossilized wood remains, the decrease in temperature during the LIA resulted in a retreat of the forest tree line at high latitudes (Kullman 2005; MacDonald et al. 2008; Linderholm et al. 2014; Kullman 2015; Helama et al. 2020) or altitudes (Camarero et al. 2015) and changes in species composition (Campbell \& McAndrews 1993). Here, we investigated whether climatic trends during and after the LIA and occurrences of extreme events had evolutionary consequences for forest tree populations. We addressed two major questions in this work. First, we investigated whether extreme events occurring during the late LIA left a genomic signature. Second, we investigated whether the shift in climate after the LIA also left a genomic imprint. We chose sessile oak (Quercus petraea (Matt.) Liebl.) as the model species for this study, as the oldest forests in Europe contain sessile oak stands that came into existence in the middle of the LIA (near 1650), a time at which the French statesman Colbert implemented even-aged management in French forests (Gallon 1752). Four age-structured cohorts of roughly 340, 170, 60 and 12 years old were sampled within three forests, to explore changes in allele frequencies over time. Quercus petraea is known to display considerable genetic diversity (Mariette et al. 2002; Kremer \& Hipp 2020; Leroy et al. 2020) and to have a high genetic variance for fitness (Alexandre et al. 2020). The selection for viability or the demographic 
dynamics generated by extreme weather events would be expected to result in changes in allelic frequency. Climate change-driven evolution over the course of a few generations has mostly been reported in invasive species (Chown et al. 2015) or in controlled experiments (Ravenscroft et al. 2015). By contrast, in this study, we explored the ability of a native species with high levels of standing genetic variation to respond to recent documented climatic changes. Our approach mirrors experiments monitoring the change in allelic frequencies over successive discrete generations in natura (Malaspinas 2016) or in controlled selection experiments (Schlotterer et al. 2015), except that our study made use of contemporary age-structured cohorts. Earlier genome-wide investigations performed with a synchronous approach in common gardens highlighted the multifaceted and unrepeatable signatures of natural selection, characterized by heterogeneous polygenicity (trait architecture determined by a large number of genes with small effects) and allelic heterogeneity (Alberto et al. 2011; Plomion et al. 2016; Rellstab et al. 2016). In two recent publications Buffalo and Coop $(2019,2020)$ showed that allele frequency trajectories can be shifted due to linked selection between selected and neutral loci and generate covariances between allelic frequency changes at successive time periods. Theoretically, the magnitude of covariances depends on the genetic variance of fitness, recombination and linkage disequilibrium between selected and neutral loci, whereas their sign depends on the maintenance or fluctuation of selection pressures over time. We hypothesized that this approach would be suitable for detecting genomic footprints of selection in the past, during the late LIA, and shifts in selection pressures due to warming after the end of the LIA. We also explored a more qualitative approach addressing the underlying functions of the multiple genes contributing to the covariances of allelic frequency changes. We thus had three objectives: (1) to retrace trends for the covariances of allelic frequencies between age-structured cohorts spanning the last three centuries in oak stands (2) to determine whether these trends were repeatable over replicated observations in three different forests, (3) to explore the gene networks involved in these responses to environmental change. 


\section{METHODS}

\section{Sampling forests and age structured cohorts}

We sampled three oak forests located in the central and western part of France (Bercé, RénoValdieu and Tronçais, Figure 1A). These forests include stands of up to 349 years of age when the study started in 2014, and are managed under even-aged silvicultural regimes (Supporting Information S1). The upper canopy consisted principally of Quercus petraea, and historical records and genetic evidence (based on chloroplast DNA haplotypes) indicated that the three forests were of natural origin (Petit et al. 2002). In each forest, we sampled individuals belonging to four age-class cohorts corresponding to ages of 340, 170, 60 and 12 years (born approximatively in 1680, 1850, 1960 and 2008) (Figure 1, Table S1). These cohorts are referred to as cohorts 4, 3, 2 and 1, respectively, below. The regeneration period, during which mature trees mate and the stand is renewed by natural seeding, takes today about 10 to 20 years, but extended over longer periods in the past (up to 30 years). The age of the trees in a given cohort may, therefore, vary by up to 10 to 30 years. Cohorts were dated on the basis of management records, together with dendrochronological recordings for a few felled trees within each cohort (Figure 1B). Knowledge of the demographic dynamics of even-aged forests is required to identify the periods during which selection was at its strongest. When a stand is renewed by natural seeding, a very dense cohort of seedlings develops (more than 100,000 seedlings/ha), the number of plants gradually decreasing to about 4,000/ha by the age of 10 years, as a result of natural selection and chance events. Crucially, subsequent silvicultural thinning is applied to only the remaining $6 \%$ of the trees. Hence, an oak stand that is about 340 years old today probably underwent its strongest bout of natural selection in the late seventeenth century, when it was at the seedling stage. Such reasoning provided the rationale for sampling age-structured cohorts in even-aged stands for retrospective monitoring of the selective impact of past climatic changes. The different cohorts within a given forest are probably derived from the same founding population established more than 10,000 years ago (Giesecke 2016; Giesecke \& Brewer 2018), but there is no direct traceable generation-to-generation link between the cohorts.

High-resolution regional and temporal temperature reconstructions based on a combination of instrumental data (for the most recent period), documentary records, ice core and tree ring proxy data revealed clear temperature trends over the last 340 years in the three forests (Luterbacher et al. 2004; Luterbacher et al. 2016) (Supporting Information S2, Figure S1). There were two cooler periods within the LIA (1660 to 1690 and 1840 to 1860 ), followed by a continuous 
increase in temperature of about $0.8^{\circ} \mathrm{C}$ from 1860 to 1950 . The two cooler periods were also dominated by more frequent extreme winters and summer drought events (Figure S2 and S3, Figure 3d). Comparing these temporal bioclimatic trends with the ages of our cohorts, the two oldest cohorts are almost synchronous with the two periods in which conditions were most severe during the LIA. Cohort 4 originated during the late $17^{\text {th }}$ century, whereas the trees of cohort 3 were established in the mid $-19^{\text {th }}$ century (Figure $1 \mathrm{~B}$ ).

\section{DNA extraction and sequencing}

Leaf samples were collected from cohort 1 in the spring and summer 2014, whereas cambium samples were harvested at the base of the trunk with a punch for the three older cohorts. The sample size for each cohort was between 40 and 68 trees (Figure 1B). DNA was extracted from the 639 samples with a Qiagen extraction kit. DNA yields were measured with a NanoDrop 1000 spectrophotometer (NanoDrop Technologies, Wilmington, DE, USA) and DNA samples were pooled in equimolar amounts within each cohort from each forest. The 12 pools ( 3 forests * 4 cohorts) were sequenced on an Illumina HiSeq4000 sequencer generating 150 bp pairedend reads.

\section{SNP discovery}

The various steps in the SNP calling pipeline were as described in (Altmann et al. 2012; Pfeifer 2017). The adapters and primers were removed and reads were trimmed to remove nucleotides with a quality value below 20 from the two ends. The sequences between the second unknown nucleotide and the end of the read were removed, and reads of less than 30 nucleotides in length were discarded. Finally, the read pairs from the low-concentration spike-in Illumina PhiX Control library were removed. We obtained a mean of 348,863,070 reads per pool (Table 1). The reads were mapped onto the v2.3 Q. robur genome assembly (Plomion et al. 2018) with bwa-mem, with a seed size of 39 (Li \& Durbin 2010). Incorrectly paired reads and reads giving multiple alignments were removed with samtools (Li et al. 2009). Duplications were removed with Picard tools (no publication, Broad Institute). Base Alignment Quality (BAQ) was calculated with samtools (Li et al. 2009). Pileup files were generated for each scaffold over all forests, with samtools. These files were converted into synchronized pileups with a minimum alignment quality of 10, and allele frequencies were calculated for SNPs with a minimum count of two for minor alleles, a minimum coverage of $40 \mathrm{X}$ and a maximum coverage of $10 \%$ of total coverage within each pool, with Popoolation2 (Kofler et al. 2011). Further filtering was applied 
to the three types of pileup files, to select biallelic SNPs with a minimum minor allele frequency of 0.02 .

\section{Diversity within and between cohorts}

Genetic diversity was estimated on non-overlapping genomic windows of 10kb spanning the whole oak genome. For each pool, we therefore generated new pileup files, including monomorphic sites. To take into account the variance in pool size and coverage among populations, we used the subsample-pileup.pl script from Popoolation2 (Kofler et al. 2011) to target a minimum coverage of 30 at each position and for each pool. These parameters were chosen after optimization in order to minimize the amount of missing data between pools. Tajima's $\pi$ (Tajima 1989) was then calculated with the variance-sliding.pl script. As for the SNP sets, sites with a minimum alignment quality of 10 were retained, and were considered polymorphic if at least two copies of the minor allele were detected among all reads. Windows with a minimum covered fraction of $50 \%$ were retained for the calculation of Tajima's $\pi$. $F_{S T}$ values were calculated for each SNP, between each pair of cohorts, using Popoolation2 (Kofler et al. 2011), and were averaged over the whole genome.

\section{Temporal covariances}

Buffalo and Coop $(2019,2020)$ have developed a method for testing for genomic signals of selection on polygenic traits due to linked selection, based on temporal covariances of allelic frequency changes. Allele frequency changes were calculated for different time spans separating the cohorts in the three replicated forests. We used the CVTK software package available from http://github.com/vsbuffalo/cvtk to calculate the temporal covariances between allelic frequency changes (Buffalo \& Coop 2020).

We filtered SNPs by removing sites with a depth below the number of alleles sampled for each cohort, and with a minor allele frequency below 0.02. Contigs were also filtered out when shorter than $200 \mathrm{~kb}$ long (excluding 'N's). Read depth and sample size were used to correct for bias in variance estimates (Buffalo \& Coop 2020). Corrections were also done for bias caused by sampling noise common to adjacent time points. This bias stems from the allele frequency at a given time point common to the terms of the covariances between adjacent time periods (e.g., for $\operatorname{Cov}\left(\Delta_{1680-1850}, \Delta_{1850-1960}\right)$, allele frequency at 1850 is included in both terms).

Genome-wide temporal covariances were then computed between pairs of non-overlapping time spans within each forest. Covariances were calculated based on all SNPs, and for all three 
forests separately. The mean and $95 \%$ confidence intervals of the covariance were obtained by bootstrapping, with 5000 iterations.

The change in the variance of allelic frequency changes over the whole period, from 1680 to 2008, becomes:

$$
\begin{gathered}
\mathrm{V} \Delta_{1680-2008}=\mathrm{V} \Delta_{1680-1850}+\mathrm{V} \Delta_{1850-1960}+\mathrm{V} \Delta_{1960-2008} \\
+2 \operatorname{Cov}\left(\Delta_{1680-1850}, \Delta_{1850-1960}\right)+2 \operatorname{Cov}\left(\Delta_{1680-1850}, \Delta_{1960-2008}\right) \\
+2 \operatorname{Cov}\left(\Delta_{1850-1960}, \Delta_{1960-2008}\right)
\end{gathered}
$$

The contribution of the temporal covariances to $\mathrm{V} \Delta_{1680-2008}$ due to linked selection thus becomes (G equation [1] of Buffalo \& Coop (2020)) :

$$
\begin{aligned}
& \mathrm{G}\left(\Delta_{1680-2008}\right) \\
& =\frac{\operatorname{Cov}\left(\Delta_{1680-1850}, \Delta_{1850-1960}\right)+2 \operatorname{Cov}\left(\Delta_{1680-1850}, \Delta_{1960-2008}\right)+2 \operatorname{Cov}\left(\Delta_{1850-1960}, \Delta_{1960-2008}\right)}{V_{1680-2008}}
\end{aligned}
$$

$\mathrm{G}$ estimates the contribution of linked selection to the variance of the allelic frequency change from the starting point to the most recent time period. Buffalo and Coop (2020) suggested that $\mathrm{G}$ can also be understood as the decrease in neutral diversity due to linked selection.

We extended this approach to the calculation of covariances between pairs of forests, $\left(\operatorname{Cov} \Delta \mathrm{X}_{\mathrm{i}-}\right.$ $\mathrm{j}, \Delta \mathrm{Y}_{\mathrm{i}-\mathrm{j}}$ ) over the same period (i-j) or at different non-overlapping time periods. The maintenance of a positive covariance would indicate similar responses and directions of selection (convergent selection) in the different forests, whereas negative values would provide evidence of differences in the direction of selection. The extension to different forests made it possible to estimate covariance over contemporary time periods, or disconnected time scales (adjacent or distant), thereby making it possible to determine whether convergent selection occurred over the same time period, or whether fluctuating selection occurred over different time periods.

\section{Gene annotation and ontology enrichment analysis}

We divided the oak genome into tiles of $100,000 \mathrm{bp}$ in length and calculated the variance and covariance for all tiles. Genomic regions with strong responses to linked selection were identified on the basis of covariance values between time intervals above 0.01 for all three replicated forests. 
The genes located in the regions with the highest covariances were annotated with various bioinformatic tools. Arabidopsis thaliana was initially used as a reference. Orthologous genes between oak and $A$. thaliana were identified for each protein sequence (file “Qrob_PM1N_CDS_aa_20161004.fa.gz", available at https://urgi.versailles.inra.fr/download/oak/) by selecting the best blast hit (blastP, pvalue < 1e+05 ) to represent the oak gene model, and Arabidopsis GO terms from TAIR were used for annotation (https://www.arabidopsis.org/). For oak genes without orthologs in Arabidopsis, we performed eggNOG-mapper v2 functional annotation based on fast orthology assignments, using precomputed eggNOG v5.0 clusters and phylogenies (Huerta-Cepas et al. 2017; HuertaCepas et al. 2019). Gene ontology (GO) terms were inferred from eggNOG orthologous groups (OGs).

Gene sets associated with Biological Processes (BP), Molecular Functions (MF), and Cellular Components (CC) were tested for GO terms enrichment with the "topGO" R package and the "weight" algorithm associated with a Fisher's exact test to select the most relevant terms (Alexa et al. 2006; Alexa \& Rahnenfuhrer 2020). A p-value < 0.05 was applied for the statistical test, and no FDR was calculated because the $p$-values returned by the "weight" method are interpreted by Alexa \& Rahnenfuhrer (2020) as corrected or not affected by multiple testing. 


\section{RESULTS}

\section{Diversity and differentiation within and between age-structured cohorts}

On average, more than 13 millions of SNPs were called in each cohort (Table 1). Within agestructured cohorts, nucleotide diversity was high $(\pi \sim 0.01205)$. Levels of diversity were similar across cohorts and forests and consistent with previous estimates for oak (Plomion et al. 2018). The mean pairwise $F_{S T}$ between cohorts ranged from 0.010 to 0.015 , with no detectable structure between cohorts and forests (Figure 2). Using Fisher exact tests, we found significantly differentiated SNPs between the consecutive cohorts 4 and 3, cohorts 3 and 2, cohorts 2 and 1 and between the distant cohorts 4 and 1 in all three forests for a limited number of SNPs in comparison to the total number of 13 millions SNPs. In Bercé the number of significantly differentiated SNPs between any two cohorts varied between 293 and 538. The range of variation was 20 to 40 in Réno-Valdieu and 45 to 1674 in Tronçais. None of these SNPs was significantly differentiated between cohorts in more than one forest. Overall these figures suggest that genome-wide differentiation between cohorts was likely due to subtle changes of allelic frequencies between different time periods.

\section{Temporal covariances of allelic frequency changes within forests}

We calculated the covariances of allelic frequency changes between proximal time periods $\left(\operatorname{Cov}\left(\Delta_{1680-1850}, \Delta_{1850-1960}\right)\right.$ and $\left.\operatorname{Cov}\left(\Delta_{1850-1960}, \Delta_{1960-2008}\right)\right)$ and distant time periods $\left(\operatorname{Cov}\left(\Delta_{1680-1850}, \Delta_{1960-2008}\right)\right)$. All proximal and distant covariances were significant in all three forests (Figure 3). The covariances between the earliest adjacent time periods $\left(\operatorname{Cov}\left(\Delta_{1680-1850}, \Delta_{1850-1960}\right)\right.$ were positive and significant in each forest (Figure 3A). The covariances between the more recent adjacent time periods $\operatorname{Cov}\left(\Delta_{1850-1960}, \Delta_{1960-2008}\right)$ varied between the three forests, being positive in Bercé, slightly lower in Réno-Valdieu and negative in Tronçais (Figure 3B). Finally, the covariances between distant time periods were much lower than those between adjacent time periods in Bercé and Réno-Valdieu, and also partially in Tronçais (Figure 3C). Overall, the patterns illustrated in Figure 3 show a shift of covariances between adjacent time periods from the earliest periods considered (1680-1850, 1850-1960) to the more recent time periods (1850-1960, 1960-2008).

We also estimated the contribution of the temporal covariances to $\mathrm{V} \Delta_{1680-2008}$ by calculating G $\Delta_{1680-2008}$ (equation 2, Table 2). The proportion of the variance of allelic frequency change due to linked selection increased from time period 4 (1680) to time period 1 (2008), due to the positive covariances in Bercé (9 to 16\%) and Réno Valdieu (18\% to 22\%). It decreased in 
Tronçais from $12 \%$ to $-1 \%$ (Table 2), due to the overall decrease in covariances between distant time periods. The largest contribution was that of the covariances for the earliest periods $\operatorname{Cov}\left(\Delta_{1680-1850}, \Delta_{1850-1960}\right)$ which were positive in all three forests, resulting in $\mathrm{G} \Delta \mathrm{X}_{1680-1960}$ values of $9 \%, 18 \%$ and $12 \%$, respectively.

\section{Temporal covariances of allelic frequency changes between forests}

Significant positive temporal covariances between forests would indicate convergent linked selection. Considering different time periods for calculating the covariances can provide an indication as to when convergent selection occurred. Does it occur at contemporary or distant time periods? We therefore calculated the covariances of allelic frequency changes between the three forests for three different time periods (Figure 4):

- Contemporary time periods (Figure 4A)

- Adjacent time periods (Figure 4B)

- Distant time periods (Figure 4C)

We did not consider overlapping time periods, to avoid the inflation of covariances due to allelic frequency changes common to the covariance terms.

Overall, covariances between forests remained positive and significant for contemporary time periods, particularly between Bercé and Réno-Valdieu and between Réno-Valdieu and Tronçais (Figure 4A). Covariances between Bercé and Tronçais were close to zero regardless of the time period considered. Leaving these latter covariances aside, there was a trend over time towards a decrease in contemporary covariances from more ancient to more recent time periods (Figure 4A). The covariances between two forests, between adjacent or distant time periods, were strikingly different from contemporary covariances, as they were all close to zero (Figure 4B and 4C).

\section{Gene ontology and enrichment analysis}

We divided all scaffolds into tiles of $100 \mathrm{~kb}$ in length and recalculated the temporal covariance of allele frequency changes for all tiles. We then identified putative regions (tiles) under linked selection on the basis of their covariances between the two earliest time intervals $\operatorname{Cov}\left(\Delta_{1680-1850}, \Delta_{1850-1960}\right)$ being above 0.01 in all three replicates. We restricted our analysis to the two earliest time intervals (yielding positive values in all three forests (Figure 3A), for which strong covariances were also observed between forests (Figure 4). In total we identified 104 tiles exhibiting temporal covariances above the threshold, which corresponded to $1 \%$ of 
the tiles (Figure S4 and S5). We inventoried 280 protein coding genes in these regions. Functional annotations of the 280 genes putatively under linked selection are summarized in Table S2. Briefly, out of these 280 genes, 248 received a GO annotation from A. thaliana, and two also received eggNOG GO terms, leaving 30 genes without a GO annotation.

The 280 genes revealed significant enrichments in the different gene ontologies (Table S3, S4, S5). Enrichment analysis identified several Biological Processes (BP), most of which are related to the "plant-type hypersensitive response", "defense response to fungus", "wax and cutin biosynthetic processes" and "anther dehiscence", with higher connectivity between the two first terms which gather 15 and 13 genes respectively (Figure 5, Table S3). Fifteen genes belong to the group "defense response to fungus", eight of which encode proteins similar to AT2G34930, a LRR disease resistance family protein, one was similar to AT3G59660 (BAGP1) required for fungal resistance, one was similar to AT5G64120 (PRX71) encoding a cell wall-binding peroxidase involved in lignification and important for fungal defense, two genes similar to AT3G51550 (FER), a plasma membrane-localized receptor-like kinase involved in fungal infection but also in flowering regulation, and three genes similar to AT1G02205 (CER1), which is associated with the production of stem epicuticular wax and pollen fertility. These multiple copies of Arabidopsis homologs correspond to tandem duplications located on chromosomes 3 (AT2G34930, 8 homologs), chromosome 12 (AT3G51550 (FER), 2 homologs) and on the unassigned scaffold Qrob_H2.3_Sc0000124 for AT1G02205 (CER1) (3 homologs), respectively (Table S2). Enrichment results highlight additional Biological Processes contributing to resistance to biotic and abiotic (Supporting Information 3). Furthermore the Molecular Function and Cellular Component ontology groups included as well genes involved in stress resistance (Supporting Information 3). 


\section{DISCUSSION}

\section{Temporal covariances as imprints of genome-wide linked selection durin and after the}

\section{LIA}

Temporal allelic frequency changes for genes underlying adaptive polygenic traits have been studied in detail through theoretical approaches (Hollinger et al. 2019; Stephan \& John 2020), simulations (Franssen et al. 2017), and empirical case studies (Long et al. 2015). Convergent predictions highlight small and subtle changes for genes targeted by directional selection, and have been supported by multi-generation selection experiments in model organisms (Burke et al. 2010; Barghi et al. 2019; Michalak et al. 2019). Our results suggest that genomic signatures of recent selection are also detected in natural populations of long-lived non-model species and over shorter time periods (or limited numbers of generations). Rapid evolution was reported at the genomic level in previous studies in non-model species in the context of rapid environmental change (Franks et al. 2018; Hamann et al. 2021) strong selection pressures (Dayan et al. 2019) or domestication (Guo et al. 2018), and this process was fueled by the presence of large amounts of standing genetic variation (Bitter et al. 2019; Dayan et al. 2019). The results we obtained in oaks meet theoretical expectations and show that tree populations are under genome-wide linked selection. Buffalo and Coop (Buffalo \& Coop 2019) showed that, under directional selection (based on an exponential fitness function), the covariances of neutral allele frequency changes over time depend on the genetic variance of fitness $\left(\mathrm{V}_{\mathrm{A}}\right)$, recombination distance $(\mathrm{R})$ and linkage disequilibrium, and found that the amount of covariances accumulated over a few generations was mainly determined by the compound factor $\mathrm{V}_{\mathrm{A}} / \mathrm{R}$. We recently reported that $Q$. petraea forest stands display substantial heritable differences in reproductive success (Alexandre et al. 2020). The genetic variance of fitness in a forest located between two of the forests studied here, Bercé and Réno-Valdieu, was 0.468 (Alexandre et al. 2020), which is at the upper end of the range of values reported in a recent review of the literature ( $89 \%$ of the reported values were below 0.20$)$ (Hendry et al. 2018). In addition, most linkage disequilibrium is present in oak populations for physical distance lower that 5000 bp (Nocchi et al. 2021), which corresponds to $0.0052 \mathrm{cM}$ taking into account the physical and genetic maps of oak (Bodenes et al. 2016; Plomion et al. 2018). The compound factor $\left(\mathrm{V}_{\mathrm{A}} / \mathrm{R}\right)$ in oaks amounts therefore to 90 , which should generate covariances varying between 0.002 and 0.004 after less than 10 generations (Buffalo and Coop (Buffalo \& Coop 2019), their Figure 4, p.1019), which is within the range observed in our study (Figure 3A and 3B). Furthermore, QTL studies of fitness-related traits in oaks (growth, phenology and 
reproduction) have shown that all these traits depend on a large number of loci (Brendel et al. 2008; Derory et al. 2010; Caignard et al. 2019), suggesting the genetic architecture of fitness is highly polygenic. Sessile oak and most likely trees in general are therefore prone to linked selection, provided that environmental constraints are strong enough for selection to operate.

Finally, the temporal allelic frequency changes assessed in our particular case study of agestructured cohorts are also potentially subject to other sources of variation that must be considered. Pollen flow between the age-structured cohorts within each forest may affect estimates of covariances. In the peculiar situation of age structured cohorts, gene flow between cohorts amplifies generation overlap. While the theory of temporal covariances generated by linked selection has been developed in the frame of discrete generation (Buffalo \& Coop 2019), it is unknown how generation overlap may impact covariances. Given the age class distributions in even-aged stands, old cohorts occupy limited surface in comparison to mid age cohorts, and gene flow is likely more frequent within the latter then between different age classes. Furthermore gene flow between cohorts reduces temporal allelic changes between cohorts and would likely blur the covariances. Our covariances may, therefore, actually have been underestimated. Finally, the confounding effects of development-related changes in fitness may have contributed to increases in covariances too. If traits contribute to fitness changes over time in a long-lived species, then genetic covariances of fitness-related traits will increase between traits assessed at similar ages. This temporal serial autocorrelation - and its decay over time - have been reported for growth in pines (Kremer 1992). Such development-related covariances are entirely confounded with temporal covariances in our case. However, we would argue that developmental covariances occurring at the adult stage are likely to have a limited impact on temporal covariances, as selection is overwhelmingly more severe at the juvenile stage, with more than $90 \%$ of oak seedlings eliminated before the age of 10 years (Jarret 2004). Ultimately, human interferences are unlikely as well to have impacted temporal trends of the covariances, as these stands have been conducted under even-aged silviculture since the seventeenth century, and because selection is at its strongest during the juvenile period when no human mediated intervention takes place (Methods, paragraph "sampling”)

\section{Shifts of temporal covariances mirror climatic transitions between the LIA and modern times}

If $Q$. petraea populations provide the necessary substrate for linked selection, what were the environmental constraints that triggered viability selection during the time periods considered? There is evidence that the LIA was a period with frequent extreme events in both summer and 
winter (Dobrovolny et al. 2010; Berchtold et al. 2012; Moreno-Chamarro et al. 2017) (Figure S2 and S3), these events being severe enough to affect natural populations of plants and animals. As illustrated in Supporting Information 2, extreme frosts and droughts were more frequent up to the late $19^{\text {th }}$ century than during more recent periods. Frost damage, including tree decline and deaths, was reported after extreme winters in the late LIA. (Hausendorff 1940) summarized historical writings about forest districts in Northern Germany mentioning recurrent episodes of adult oak tree mortality during the 1740-1748 period, following the extreme winter of 17391740 (Hausendorff 1940). Many historical documents from Catholic parishes reported extensive tree losses (fruit and forest trees, including walnuts, plum trees, oaks and chestnuts) following the winter of 1708-1709, which is known to be the most severe winter in European records (Avila \& Avila 1987; Luterbacher et al. 2004). In Eastern France, a historical atlas dating from 1758 reported "The dead material was mainly oak. For example, forty six oak high forests belonging to all categories were totally dead." This high mortality was presumably attributed to the extreme winter of 1708-1709 (Schnitzler 2020). However, the climate improved after 1850. There were only three reported extreme winters (1942, 1947 and 1963) and three extreme droughts $(1921,1934,1976)$ during the $20^{\text {th }}$ century (Figure S2 and S3), during which oak decline was also recorded, but not the same extent as previously (Delatour 1983). These extreme events and the shift in their occurrence over time (during the second half of the $19^{\text {th }}$ century) may be responsible for generating the pattern of linked selection observed in this study.

As pointed out in the M\&M part, selection intensity at the seedlings stage is extremely high and the size of the seedling population very large. Theory (Buffalo \& Coop 2019) and empirical data from selection experiments (Buffalo \& Coop 2020) suggest that, if the direction of selection is maintained over time, covariances tend to be positive, whereas shifts of directional selection are likely to decrease covariances, possibly resulting in negative values. In experimental selection, in which the direction of selection is maintained over successive generations, temporal covariances are predicted to decay as a result of recombination (Buffalo \& Coop 2019). In natural populations, heritable fitness differences, the strength and shifts of direction of selection, and recombination are the drivers of the temporal covariances. The widespread and frequent occurrence of extreme frosts and drought events up to the late $19^{\text {th }}$ century in Europe may therefore be responsible for the positive covariance observed between the two earliest time periods (1680-1850 and 1850-1960, Figure 3A) within each forest and for the positive covariances at contemporary time scales between forests (Figure 4A). Conversely, 
the lower, and even negative covariances between the two more recent time periods (1850-1960 and 1960-2008, Figure 3B) may be a genomic signature of the change in the frequency of extreme events between the mid-19 ${ }^{\text {th }}$ century and today. The maintenance of positive (or negative) covariances between adjacent time periods is reinforced by the limited impact of recombination in our study case. The short time interval between cohorts would have prevented opportunities for recombination events to break the linked polymorphisms. The time trends for covariances between forests support the interpretation that the strength and shifts of selection since the late LIA have shaped signatures of linked selection. Between-forest covariances were higher and more consistent across forests during the late LIA, when climatic conditions were harsher than the milder climatic conditions observed in the late $20^{\text {th }}$ century (Figure 4).

\section{Biotic interactions driven by adaptive response to climate}

The functional analysis highlighted significant enrichments for genes involved mainly in plant defense responses to pathogens, or contributing to abiotic stress responses (temperature and drought) (Figure 5). Many of the genes encoding resistance proteins (R proteins) belong to the NBS-LRR families. These R-genes are widely represented in the oak genome, in which they appear as expanded groups (Plomion et al. 2018). R-proteins are involved in pathogen recognition and the subsequent activation of innate immune responses. Most R-proteins contain a central nucleotide-binding domain, the so-called "NB-ARC" domain, a TIR or CC N-terminal domain and a C-terminal LRR domain. The NB-ARC domain is a functional ATPase domain, and its nucleotide-binding state is thought to regulate the activity of the R protein. Such NBSLRR receptors detect effectors used by pathogens to facilitate infection, and participate in the signaling cascade leading to various responses preventing further infection, such as the hypersensitive response, the production of reactive oxygen species and cell wall modification (Boyes et al. 1998; Roux 2010; El Kasmi et al. 2017). Interestingly two homologs of genes RPM1 and EFR were both involved in plant defense against Pseudomonas syringae (Boyes et al. 1998) which can infect a wide range of herbaceous and woody plants that have suffered frost and freezing damage (Young et al. 1988; Luisetti et al. 1991; Balestra et al. 2009). In addition, five genes encoding beta-glucosidases that could confer freezing/cold tolerance were identified (Thorlby et al. 2004; Fourrier et al. 2008; Ambroise et al. 2020). These genes may also participate in responses to other biotic/abiotic stresses (Baba et al. 2017; Vassao et al. 2018). Our functional analysis is consistent with the oak responses described in cases of oak decline ultimately leading to the death of the tree. Botanic and pathological descriptions of oak decline during the LIA are lacking, but reports of recurrent sparse oak dieback in more recent decades 
can be used to retrace the steps leading to oak death following severe winter or drought events. In a review of oak decline in Europe, Thomas et al. (2002) highlighted the combined effects of climatic extremes (drought or frost) and defoliating insects and pathogenic fungi (Thomas et al. 2002). The starting point is an extreme climatic event that weakens the trees (Vanoni et al. 2016), which is then followed by pest and insect attacks, which ultimately kill the tree. For example, episodes of oak decline in the first half of the $19^{\text {th }}$ century in various parts of Europe were caused by a combination of winter frost, summer drought, insect defoliation (caused by oak leaf roller (Tortrix viridana) and oak processionary moth Thaumetopoea processionea), and several pathogenic fungi (mainly powdery mildew Erisyphe alphitoides) and root pathogens (Armillaria and Phythopthora) (Delatour 1983; Donaubauer 1998; Thomas et al. 2002). The effect of drought or frost driving pathogen and insects dynamics has been reported in other oak species, e.g. in Mediterranean oaks (Colangelo et al. 2018) and American red oaks (Wood et al. 2018). In summary, extreme events, such as severe frost or drought, expose trees not only to abiotic stresses, but also to biotic selection pressures. These, in turn, trigger resistance responses, which were identified at genomic level in the functional analysis. We suspect that these processes also operated during the late LIA and that exposure to selection was more stringent, leading more widespread death (Hausendorff 1940; Schnitzler 2020), and, ultimately, to convergent linked selection across the three forests.

\section{CONCLUSION}

Our results clearly show that selection has been operating at recent and contemporary time scales in long-lived species such as oaks, but in different directions during cold and warm periods. Patterns of covariance changes indicate that selection intensity and direction fluctuated during the last three centuries, reflecting changes in climatic conditions. Evolution over short time periods may play a more important role in trees than previously thought, but its effects may be partially erased over longer periods if selection fluctuates. Beyond oaks, other woody species sharing similar life history traits and attributes (large standing genetic, polygenicity of fitness, high fecundity and severe selection screening at the juvenile stage..) may as well be prone to linked selection and allow retrospective tracking of evolutionary and adaptive pathways. Such retrospective approaches may improve our understanding of future responses to ongoing climatic changes. Finally our findings may lead also to practical silvicultural implications. Our conclusions raise concerns about the maladaptation of old centennial trees under current climate conditions. They were exposed to different selection pressures driving different adaptive responses. And today they may swamp younger oak stands by maintaining a 
temporal "migration load" by pollen flow. Our findings argue therefore for a decrease of generation time in managed oak forest to overcome maladaptation of old extant cohorts and "migration load".

\section{Acknowledgements}

This research was supported by the European Research Council through an Advanced Grant (project TREEPEACE \# FP7-339728), by France Génomique (project EVOL-OAK, ANR-10INBS-09-08), and by the French Forest Service (ONF) (INRAE-ONF TREEPEACE contract). Jun Chen was financed by the National Natural Science Foundation of China (31972946). We thank the staff of the ONF Research and Development Department (Myriam Legay, Lucie Arnaudet) and the ONF staff at the National Forests of Bercé, Réno-Valdieu and Tronçais (Anthony Jeanneau, Vincent Breton, Benjamin Laurendeau, Loïc Nicolas, Alexandre Durin) for technical assistance during the sampling of cohorts and trees. We acknowledge the contribution of Niklaus Zimmermann (WSL, Birmensdorf, Switzerland) for downscaling the historical climatic data. We thank Leo Arnoux, Sylvain Delzon, Patrick Reynet, and Florine Routier (UMR BIOGECO) for collecting bud, leaf and cambium samples for the 12 cohorts. We thank Alexis Ducousso (UMR BIOGECO) for assistance with forest selection, and Benjamin Brachi and Santiago Gonzalez-Martinez (UMR BIOGECO) for fruitful discussions during data analysis. We thank the Genotoul Bioinformatics Platform (Bioinfo Genotoul) at Toulouse (France) for providing computing and storage resources, and the Genoscope (CEA, Commissariat à l'Energie Atomique et aux Energies Alternatives) at Evry (France) for sequencing the oak samples. We thank Vince Buffalo for his helpful comments on an earlier version of the manuscript.

\section{Authors contribution.}

Conception and coordination of the study: A.K., C.P., M.L.; Sampling of forests and cohorts: A.K., F.M., L.T.; Collection of samples and DNA extraction: L.T., B.D., C.L., A.K., T.L., D.B.; Dendrochronological analysis: D.B., F.L.; Whole genome sequencing: J.M.A., K.L., C.P.; Bioinformatic analysis: D.S., I.L., J.C., T.L.; Enrichment analysis: J.C.L.; Data analysis: D.S., J.C., A.K., M.L.; Writing of the manuscript: D.S., J.C., J.C.L., A.K., M.L., T.L. All authors reviewed the manuscript. 


\section{References}

Alberto, F., Bouffier, L., Louvet, J.M., Lamy, J.B., Delzon, S. \& Kremer, A. (2011). Adaptive responses for seed and leaf phenology in natural populations of sessile oak along an altitudinal gradient. Journal of Evolutionary Biology, 24, 1442-1454.

Alexa, A. \& Rahnenfuhrer, J. (2020). topGO: Enrichment Analysis for Gene Ontology. R package version

2.40.0. https://bioconductor.org/packages/release/bioc/html/topGO.html.

Alexa, A., Rahnenfuhrer, J. \& Lengauer, T. (2006). Improved scoring of functional groups from gene expression data by decorrelating GO graph structure. Bioinformatics, 22, 16001607.

Alexandre, H., Truffaut, L., Klein, E., Ducousso, A., Chancerel, E., Lesur, I. et al. (2020). How does contemporary selection shape oak phenotypes? Evolutionary Applications, 13, 2772-2790.

Altmann, A., Weber, P., Bader, D., Preuss, M., Binder, E.B. \& Muller-Myhsok, B. (2012). A beginners guide to SNP calling from high-throughput DNA-sequencing data. Human Genetics, 131, 1541-1554.

Ambroise, V., Legay, S., Guerriero, G., Hausman, J.F., Cuypers, A. \& Sergeant, K. (2020). The Roots of Plant Frost Hardiness and Tolerance. Plant and Cell Physiology, 61, 3-20.

Anchukaitis, K.J., Wilson, R., Briffa, K.R., Buntgen, U., Cook, E.R., D'Arrigo, R. et al. (2017). Last millennium Northern Hemisphere summer temperatures from tree rings: Part II, spatially resolved reconstructions. Quaternary Science Reviews, 163, 1-22.

Avila, F. \& Avila, M. (1987). Le froid de Janvier 1985 et les grands hivers passés dans le SudOuest de la France. Revue géographique des Pyrénées et du Sud Ouest, 58, 5-22.

Baba, S.A., Vishwakarma, R.A. \& Ashraf, N. (2017). Functional Characterization of CsBGlu12, a beta-Glucosidase from Crocus sativus, Provides Insights into Its Role in Abiotic Stress through Accumulation of Antioxidant Flavonols. Journal of Biological Chemistry, 292, 4700-4713.

Balestra, G.M., Perestrelo, L., Mazzaglia, A. \& Rossetti, A. (2009). First report of blossom blight caused by Pseudomonas syringae on kiwi fruit in Portugal. Journal of Plant Pathology, 91, 231-231.

Barghi, N., Tobler, R., Nolte, V., Jaksic, A.M., Mallard, F., Otte, K.A. et al. (2019). Genetic redundancy fuels polygenic adaptation in Drosophila. Plos Biology, 17.

Berchtold, J., Le Roy Ladurie, E., Sermain, J.-P. \& Vasak, A. (2012). Canicules et froids extrêmes. Hermann, Paris.

Bitter, M.C., Kapsenberg, L., Gattuso, J.P. \& Pfister, C.A. (2019). Standing genetic variation fuels rapid adaptation to ocean acidification. Nature Communications, 10.

Bodenes, C., Chancerel, E., Ehrenmann, F., Kremer, A. \& Plomion, C. (2016). High-density linkage mapping and distribution of segregation distortion regions in the oak genome. DNA Research, 23, 115-124.

Boyes, D.C., Nam, J. \& Dangl, J.L. (1998). The Arabidopsis thaliana RPM1 disease resistance gene product is a peripheral plasma membrane protein that is degraded coincident with the hypersensitive response. Proceedings of the National Academy of Sciences of the United States of America, 95, 15849-15854. 
Brendel, O., Le Thiec, D., Scotti-Saintagne, C., Bodenes, C., Kremer, A. \& Guehl, J.M. (2008). Quantitative trait loci controlling water use efficiency and related traits in Quercus robur L. Tree Genetics \& Genomes, 4, 263-278.

Buffalo, V. \& Coop, G. (2019). The linked selection signature of rapid adaptation in temporal genomic data. Genetics, 213, 1007-1045.

Buffalo, V. \& Coop, G. (2020). Estimating the genome-wide contribution of selection to temporal allele frequency change. Proceedings of the National Academy of Sciences of the United States of America, 117, 20672-20680.

Burke, M.K., Dunham, J.P., Shahrestani, P., Thornton, K.R., Rose, M.R. \& Long, A.D. (2010). Genome-wide analysis of a long-term evolution experiment with Drosophila. Nature, 467, 587-U111.

Caignard, T., Delzon, S., Bodenes, C., Dencausse, B. \& Kremer, A. (2019). Heritability and genetic architecture of reproduction-related traits in a temperate oak species. Tree Genetics \& Genomes, 15.

Camarero, J.J., Garcia-Ruiz, J.M., Sangusa-Barreda, G., Galvan, J.D., Alla, A.Q., Sanjuan, Y. et al. (2015). Recent and intense dynamics in a formerly static Pyrenean treeline. Arctic Antarctic and Alpine Research, 47, 773-783.

Campbell, I.D. \& McAndrews, J.H. (1993). Forest disequilibrium caused by rapid Little Ice Age cooling. Nature, 366, 336-338.

Carrer, M. \& Urbinati, C. (2006). Long-term change in the sensitivity of tree-ring growth to climate forcing in Larix decidua. New Phytologist, 170, 861-871.

Chown, S.L., Hodgins, K.A., Griffin, P.C., Oakeshott, J.G., Byrne, M. \& Hoffmann, A.A. (2015). Biological invasions, climate change and genomics. Evolutionary Applications, 8, 23-46.

Colangelo, M., Camarero, J.J., Borghetti, M., Gentilesca, T., Oliva, J., Redondo, M.A. et al. (2018). Drought and Phytophthora Are Associated With the Decline of Oak Species in Southern Italy. Frontiers in Plant Science, 9.

Cook, E.R., Seager, R., Kushnir, Y., Briffa, K.R., Buntgen, U., Frank, D. et al. (2015). Old World megadroughts and pluvials during the Common Era. Science Advances, 1.

Corona, C., Guiot, J., Edouard, J.L., Chalie, F., Buntgen, U., Nola, P. et al. (2010). Millenniumlong summer temperature variations in the European Alps as reconstructed from tree rings. Climate of the Past, 6, 379-400.

Dayan, D.I., Du, X., Baris, T.Z., Wagner, D.N., Crawford, D.L. \& Oleksiak, M.F. (2019). Population genomics of rapid evolution in natural populations: polygenic selection in response to power station thermal effluents. Bmc Evolutionary Biology, 19.

Delatour, C. (1983). Les dépérissements de chênes en Europe. Revue Forestière Française, 35 , 265-282.

Derory, J., Scotti-Saintagne, C., Bertocchi, E., Le Dantec, L., Graignic, N., Jauffres, A. et al. (2010). Contrasting relations between diversity of candidate genes and variation of bud burst in natural and segregating populations of European oaks. Heredity, 105, 401-411.

Dobrovolny, P., Moberg, A., Brazdil, R., Pfister, C., Glaser, R., Wilson, R. et al. (2010). Monthly, seasonal and annual temperature reconstructions for Central Europe derived from documentary evidence and instrumental records since AD 1500. Climatic Change, 101, 69-107. 
Donaubauer, E. (1998). Die Bedeutung von Krankheitserregern beim gegenwärtigen Eichensterben in Europa-eine Literaturübersicht. European Journal of Forest Pathology, 28, 91-98.

Edouard, J.-L., Corona, C., Thomas, A., Guibal, F. \& Denelle, N. (2009). Le petit âge glaciaire dans les cernes de croissance des arbres des Alpes françaises. Approche dendrochronoligical. Archeologie du Midi Médiéval, 27, 169-177.

El Kasmi, F., Chung, E.H., Anderson, R.G., Li, J.Y., Wan, L., Eitas, T.K. et al. (2017). Signaling from the plasma-membrane localized plant immune receptor RPM1 requires self-association of the full-length protein. Proceedings of the National Academy of Sciences of the United States of America, 114, E7385-E7394.

Fagan, B. (2002). The little ice age. How climate made history (1300-1850). Basic Books, New York.

Fourrier, N., Bedard, J., Lopez-Juez, E., Barbrook, A., Bowyer, J., Jarvis, P. et al. (2008). A role for sensitive to freezing2 in protecting chloroplasts against freeze-induced damage in Arabidopsis. Plant Journal, 55, 734-745.

Franks, S.J., Hamann, E. \& Weis, A.E. (2018). Using the resurrection approach to understand contemporary evolution in changing environments. Evolutionary Applications, 11, 1728.

Franssen, S.U., Kofler, R. \& Schlotterer, C. (2017). Uncovering the genetic signature of quantitative trait evolution with replicated time series data. Heredity, 118, 42-51.

Gallon, D. (1752). Conférence de l'ordonnance de Louis XIV du mois d'Aout 1969 sur le fait des Eaux et Forêts. Brunet, Paris.

Giesecke, T. (2016). Did thermophilous trees spread into central Europe during the Late Glacial? New Phytologist, 212, 15-18.

Giesecke, T. \& Brewer, S. (2018). Notes on the postglacial spread of abundant European tree taxa. Vegetation History and Archaeobotany, 27, 337-349.

Guo, J.Z., Tao, H.X., Li, P.F., Li, L., Zhong, T., Wang, L.J. et al. (2018). Whole-genome sequencing reveals selection signatures associated with important traits in six goat breeds. Scientific Reports, 8 .

Hamann, E., Pauli, C.S., Joly-Lopez, Z., Groen, S.C., Rest, J.S., Kane, N.C. et al. (2021). Rapid evolutionary changes in gene expression in response to climate fluctuations. Molecular Ecology, 30, 193-206.

Hausendorff, E. (1940). Frostschäden an Eichen. Aus der Geschichte des Forstamtes Grimmitz/Uckermarck. Zeitschrift für Forst-und Jagdwesen, 72, 3-35.

Helama, S., Kuoppamaa, M. \& Sutinen, R. (2020). Subaerially preserved remains of pine stemwood as indicators of late Holocene timberline fluctuations in Fennoscandia, with comparisons of tree-ring and $14 \mathrm{C}$ dated depositional histories of subfossil trees from dry and wet sites. Review of palaeobotany and palynology 278, 104223

Hendry, A.P., Schoen, D.J., Wolak, M.E. \& Reid, J.M. (2018). The Contemporary Evolution of Fitness. Annual Review of Ecology, Evolution, and Systematics, 49, 457-476.

Hollinger, I., Pennings, P.S. \& Hermisson, J. (2019). Polygenic adaptation: From sweeps to subtle frequency shifts. Plos Genetics, 15. 
Huerta-Cepas, J., Forslund, K., Coelho, L.P., Szklarczyk, D., Jensen, L.J., von Mering, C. et al. (2017). Fast Genome-Wide Functional Annotation through Orthology Assignment by eggNOG-Mapper. Molecular Biology and Evolution, 34, 2115-2122.

Huerta-Cepas, J., Szklarczyk, D., Heller, D., Hernandez-Plaza, A., Forslund, S.K., Cook, H. et al. (2019). eggNOG 5.0: a hierarchical, functionally and phylogenetically annotated orthology resource based on 5090 organisms and 2502 viruses. Nucleic Acids Research, 47, D309-D314.

Jarret, P. (2004). Chênaie atlantique. Lavoisier.

Kofler, R., Orozco-terWengel, P., De Maio, N., Pandey, R.V., Nolte, V., Futschik, A. et al. (2011). PoPoolation: A Toolbox for Population Genetic Analysis of Next Generation Sequencing Data from Pooled Individuals. Plos One, 6.

Kremer, A. (1992). Predictions of age-age correlations of total height based on serial correlations between increments in Maritime pine (Pinus pinaster Ait.). Theoretical and Applied Genetics, 85, 152-158.

Kremer, A. \& Hipp, A.L. (2020). Oaks: an evolutionary success story. New Phytologist, 226, 987-2011.

Kullman, L. (2005). Pine (Pinus sylvestris) treeline dynamics during the past millennium - a population study in west-central Sweden. Annales Botanici Fennici, 42, 95-106.

Kullman, L. (2015). Higher than present Medieval pine (Pinus sylvestris) treeline along the Swedish Scandes. Landscape online, 42, 1-14.

Le Roy Ladurie, E. (2004). Histoire humaine et comparée du climat. Canicules et glaciers XIIIième-XVIIIième siècles. Fayard, Paris.

Le Roy Ladurie, E. (2006). Histoire humaine et comparée du climat. Disettes et révolutions 1740-1860. Fayard, Paris.

Leroy, T., Louvet, J.M., Lalanne, C., Le Provost, G., Labadie, K., Aury, J.M. et al. (2020). Adaptive introgression as a driver of local adaptation to climate in European white oaks New Phytologist, 226, 1171-1182.

Li, H. \& Durbin, R. (2010). Fast and accurate long-read alignment with Burrows-Wheeler transform. Bioinformatics, 26, 589-595.

Li, H., Handsaker, B., Wysoker, A., Fennell, T., Ruan, J., Homer, N. et al. (2009). The Sequence Alignment/Map format and SAMtools. Bioinformatics, 25, 2078-2079.

Linderholm, H.W., Zhang, P., Gunnarson, B.E., J., B., Farahat, E., Fuentes, M. et al. (2014). Growth dynamics of tree-line and lake-shore Scots Pine (Pinus Sylvestris L.) in the Central Scandinavian Mountains during the Medieval Climate anomaly and the early Little Ice Age. Frontiers in Ecology and Evolution, 2, 20.

Long, A., Liti, G., Luptak, A. \& Tenaillon, O. (2015). Elucidating the molecular architecture of adaptation via evolve and resequence experiments. Nature Reviews Genetics, 16, 567-582.

Luisetti, J., Gaignard, J.L. \& Devaux, M. (1991). Pseudomonas syringae pv syringae as one of the factors affecting the ice nucleation of grapevine buds in controlled conditions. Journal of phytopathology, 133, 334-344. 
Luterbacher, J., Dietrich, D., Xoplaki, E., Grosjean, M. \& Wanner, H. (2004). European seasonal and annual temperature variability, trends, and extremes since 1500. Science, 303, 1499-1503.

Luterbacher, J., Werner, J.P., Smerdon, J.E., Fernandez-Donado, L., Gonzalez-Rouco, F.J., Barriopedro, D. et al. (2016). European summer temperatures since Roman times. Environmental Research Letters, 11.

MacDonald, G.M., Kremenetski, K.V. \& Beilman, D.W. (2008). Climate change and the northern Russian treeline zone. Philosophical Transactions of the Royal Society BBiological Sciences, 363, 2285-2299.

Malaspinas, A.S. (2016). Methods to characterize selective sweeps using time serial samples: an ancient DNA perspective. Molecular Ecology, 25, 24-41.

Mariette, S., Cottrell, J., Csaikl, U.M., Goikoechea, P., Konig, A., Lowe, A.J. et al. (2002). Comparison of levels of genetic diversity detected with AFLP and microsatellite markers within and among mixed Q-petraea (MATT.) LIEBL. and Q-robur L. stands. Silvae Genetica, 51, 72-79.

Michalak, P., Kang, L., Schou, M.F., Garner, H.R. \& Loeschcke, V. (2019). Genomic signatures of experimental adaptive radiation in Drosophila. Molecular Ecology, 28, 600-614.

Moreno-Chamarro, E., Zanchettin, D., Lohmann, K., Luterbacher, J. \& Jungclaus, J.H. (2017). Winter amplification of the European Little Ice Age cooling by the subpolar gyre. Scientific Reports, 7.

Nocchi, G., Brown, N., Coker, T., Plumb, W., Stocks, J., Denmann, S. et al. (2021). Genomic structure and diversity of oak populations in British parklands. BioRxiv. https://doi.org/10.1101/2021.03.05.434114

Palmer, W.C. (1965). Meteorological drought. US Department of Commerce, Weather Bureau, Washington.

Parker, G. (2013). Global crisis. War, climate change and catastrophe in the seventeenth century. Yale University Press, New Haven.

Petit, R.J., Csaikl, U.M., Bordacs, S., Burg, K., Coart, E., Cottrell, J. et al. (2002). Chloroplast DNA variation in European white oaks - Phylogeography and patterns of diversity based on data from over 2600 populations. Forest Ecology and Management, 156, 5-26.

Pfeifer, S.P. (2017). From next-generation resequencing reads to a high-quality variant data set. Heredity, 118, 111-124.

Pfister, C. (1984). Das Klima der Schweiz von 1525-1860 und seine Bedeutung in der Geschichte von Bevölkerung und Landwitrschaft. Volume 2. Bevölkerung, Klima und Agrarmodernisierung 1525-1860. Paul Haupt, Bern.

Plomion, C., Aury, J.M., Amselem, J., Alaeitabar, T., Barbe, V., Belser, C. et al. (2016). Decoding the oak genome: public release of sequence data, assembly, annotation and publication strategies. Molecular Ecology Resources, 16, 254-265.

Plomion, C., Aury, J.M., Amselem, J., Leroy, T., Murat, F., Duplessis, S. et al. (2018). Oak genome reveals facets of long lifespan. Nature Plants, 4, 440-452.

Ravenscroft, C.H., Whitlock, R. \& Fridley, J.D. (2015). Rapid genetic divergence in response to 15 years of simulated climate change. Global Change Biology, 21, 4165-4176. 
Rellstab, C., Zoller, S., Walthert, L., Lesur, I., Pluess, A.R., Graf, R.E. et al. (2016). Signatures of local adaptation in candidate genes of oaks (Quercus spp.) with respect to present and future climatic conditions. Molecular Ecology, 25, 5907-5924.

Rousseau, D. (2012). Identification des grands hivers de 1676 à 2010 à l'aide de séries thermométriques de Paris. In: Canicules et froids extrêmes (eds. Berchtold, J, Le Roy Ladurie, E, Sermain, J-P \& Vasak, A). Hermann Paris, pp. 345-360.

Roux, M. (2010). Identification and characterization of EFR interacting proteins. The University of East Anglia.

Schlotterer, C., Kofler, R., Versace, E., Tobler, R. \& Franssen, S.U. (2015). Combining experimental evolution with next-generation sequencing: a powerful tool to study adaptation from standing genetic variation. Heredity, 114, 431-440.

Schnitzler, A. (2020). Spontaneous landscape dynamics in the Pays de Bitche, Lorraine (France), during the Little Ice Age. Landscape history, 41, 89-104.

Stephan, W. \& John, S. (2020). Polygenic Adaptation in a Population of Finite Size. Entropy, 22.

Tajima, F. (1989). Statistical method for testing the neutral mutation hypothesis by DNA polymorphism. . Genetics, 123, 585-595.

Thomas, F.M., Blank, R. \& Hartmann, G. (2002). Abiotic and biotic factors and their interactions as causes of oak decline in Central Europe. Forest Pathology, 32, 277-307.

Thorlby, G., Fourrier, N. \& Warren, G. (2004). The sensitive to freezing2 gene, required for freezing tolerance in Arabidopsis thaliana, encodes a beta-Glucosidase. Plant Cell, 16, 2192-2203.

Tkachuck, R.D. (1983). The Little Ice Age. Origins, 10, 51-65.

van der Schrier, G., Barichivich, J., Briffa, K.R. \& Jones, P.D. (2013). A scPDSI-based global data set of dry and wet spells for 1901-2009. Journal of Geophysical ResearchAtmospheres, 118, 4025-4048.

Vanoni, M., Bugmann, H., Notzli, M. \& Bigler, C. (2016). Drought and frost contribute to abrupt growth decreases before tree mortality in nine temperate tree species. Forest Ecology and Management, 382, 51-63.

Vassao, D.G., Wielsch, N., Gomes, A., Gebauer-Jung, S., Hupfer, Y., Svatos, A. et al. (2018). Plant Defensive beta-Glucosidases Resist Digestion and Sustain Activity in the Gut of a Lepidopteran Herbivore. Frontiers in Plant Science, 9.

Wood, J.D., Knapp, B.O., Muzika, R.M., Stambaugh, M.C. \& Gu, L.H. (2018). The importance of drought-pathogen interactions in driving oak mortality events in the Ozark Border Region. Environmental Research Letters, 13.

Young, J.M., Cheesmur, G.J., Welham, F.V. \& Henshall, W.R. (1988). Bacterial blight of kiwi fruit. Annals of Applied Biology, 112, 91-105. 
Table 1 SNP diversity statistics of the age structured cohorts

\begin{tabular}{ccccc}
\hline Forest & Cohort & $\begin{array}{c}\text { Number of reads after } \\
\text { post-processing }\end{array}$ & $\begin{array}{c}\text { Number of } \\
\text { SNPs }\end{array}$ & $\pi \pm$ standard deviation \\
\hline \multirow{2}{*}{ Bercé } & B1 & $427,365,137$ & $13,277,388$ & $0.01202 \pm 5.10^{-5}$ \\
& B2 & $444,637,716$ & $13,533,867$ & $0.01208 \pm 5.10^{-5}$ \\
& B3 & $450,468,871$ & $13,586,680$ & $0.01334 \pm 8.10^{-5}$ \\
& B4 & $439,841,819$ & $13,334,778$ & $0.01447 \pm 1.10^{-6}$ \\
Réno- & R1 & $421,851,747$ & $13,344,026$ & $0.01211 \pm 5.10^{-5}$ \\
& R2 & $443,414,110$ & $13,678,790$ & $0.01256 \pm 5.10^{-5}$ \\
& R3 & $435,807,782$ & $13,518,651$ & $0.01203 \pm 5.10^{-5}$ \\
Tronçais & R4 & $440,543,051$ & $13,605,834$ & $0.01206 \pm 5.10^{-5}$ \\
& T1 & $543,901,014$ & $15,592,854$ & $0.01351 \pm 7.10^{-5}$ \\
& T2 & $440,923,574$ & $13,457,837$ & $0.01208 \pm 5.10^{-5}$ \\
& T3 & $437,816,360$ & $13,704,258$ & $0.01215 \pm 5.10^{-5}$ \\
& T4 & $432,251,274$ & $13,514,365$ & $0.01208 \pm 5.10^{-5}$ \\
\hline
\end{tabular}

Table 2 Contribution of the covariances between allelic frequency changes to the variance of allelic frequency changes between two time points.

\begin{tabular}{llll}
\hline & Bercé & Réno-Valdieu & Tronçais \\
\hline$G \Delta_{1680-1960}$ & 0.085 & 0.179 & 0.119 \\
\hline$G \Delta_{1680-2008}$ & 0.163 & 0.221 & -0.009 \\
\hline
\end{tabular}

$G$ 1680-1960: contribution of temporal covariances to the variance of allelic frequency changes from 1680 to 1960 . $G \Delta_{1680-1850}$ equals 0 as there is no covariance for the first time period. 
Figure 1. Sampling of forests and age structured cohorts of sessile oak

(A)Distribution of age structured cohorts of sessile oak in three even-aged managed national forests in France. Each forest is subdivided in compartments (about 20ha in size) limited by the black lines on the forest maps. Age class compartments are evenly distributed in the forests. Densities are extremeley high at the seedling stage ( $>100,0000 /$ ha) and decrease very rapidly due to natural selection during the early stage $(\approx 4,000$ at age 10$)$.

(B) Age, area, size of age structured cohorts. Dendrochronological data of tree rings on felled trees in each cohort allowed to confirm documentary records of trees ages . About 50 trees were randomly sampled in each cohort for whole genome sequencing. 


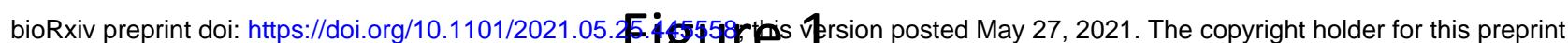
(which was not certified by peer review) is the author/furder, Who trastgranted bioRxiv a license to display the preprint in perpetuity. It is made available under aCC-BY-NC-ND 4.0 International license.

(A) Geographic distribution of age structured cohorts in three even-aged managed state fo-

(B) Age, area, and size of age structured cohorts

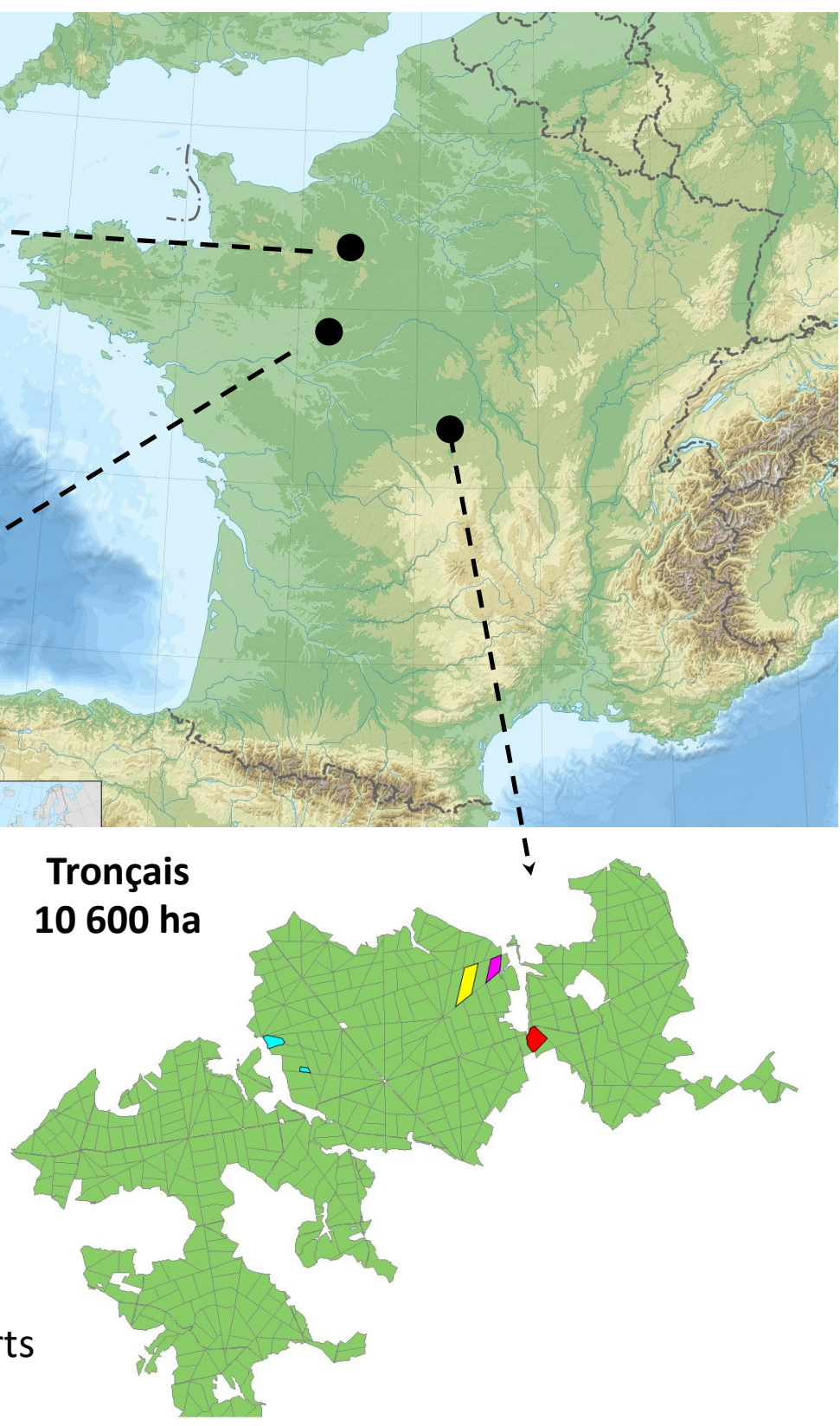

\begin{tabular}{lccccc}
\hline Forest & Cohort & $\begin{array}{c}\text { Dates of birth ac- } \\
\text { cording to manage- } \\
\text { ment documents }\end{array}$ & $\begin{array}{c}\text { Dates of birth accord- } \\
\text { ing to dendrochrono- } \\
\text { logical data * }\end{array}$ & $\begin{array}{c}\text { Surface of } \\
\text { compartment } \\
\text { (ha) }\end{array}$ & $\begin{array}{c}\text { Sample } \\
\text { size }\end{array}$ \\
\hline Bercé & B1 & $2003-2013$ & & 20 & 53 \\
& B2 & 1957 & $1954-1963(3)$ & 28 & 53 \\
& B3 & 1855 & $1856-1858(3)$ & 28 & 44 \\
\hline Réno- & B4 & 1687 & $1675-1713(18)$ & 21 & 40 \\
Valdieu & R1 & $2001-2010$ & & 10 & 55 \\
& R2 & 1959 & $1959-1973(26)$ & 10 & 68 \\
& R3 & 1854 & $1820-1857(3)$ & 12 & 54 \\
\hline Tronçais & R4 & 1704 & $1665-1731(10)$ & 13 & 56 \\
& T1 & $2002-2010$ & & 35 & 55 \\
& T2 & 1961 & $1953-1962(10)$ & 19 & 55 \\
& T3 & 1833 & $1841-1852(3)$ & 16 & 53 \\
\hline
\end{tabular}

*Minimum and maximum dates assessed on the rings of the stump. Numbers within brackets indicate the number of trees felled for the assessment. 
Figure 2 Fst values between age-structured cohorts in the three forests (B: Bercé; R: RénoValdieu; T: Tronçais).

Subscripts to forest acronyms indicate the ages of the cohorts:

4: age $\sim 340$ or year of birth $\sim 1680$

3 : age $\sim 170$ or year of birth $\sim 1850$

4: age $\sim 60$ year of birth $\sim 1960$

1: age $\sim 12$ or year of birth $\sim 2008$ 
bioRxiv preprint doi: https://doi.org/10.1101/2021.05.25.445558; this version posted May 27, 2021. The copyright holder for this preprint

(which was not certified by peer review) is the author/funder, who has granted bioRxiv a license to display the preprint in perpetuity. It is made available under aCC-BY-NC-ND 4.0 International license.

FIGURE 2

\section{Color Key}
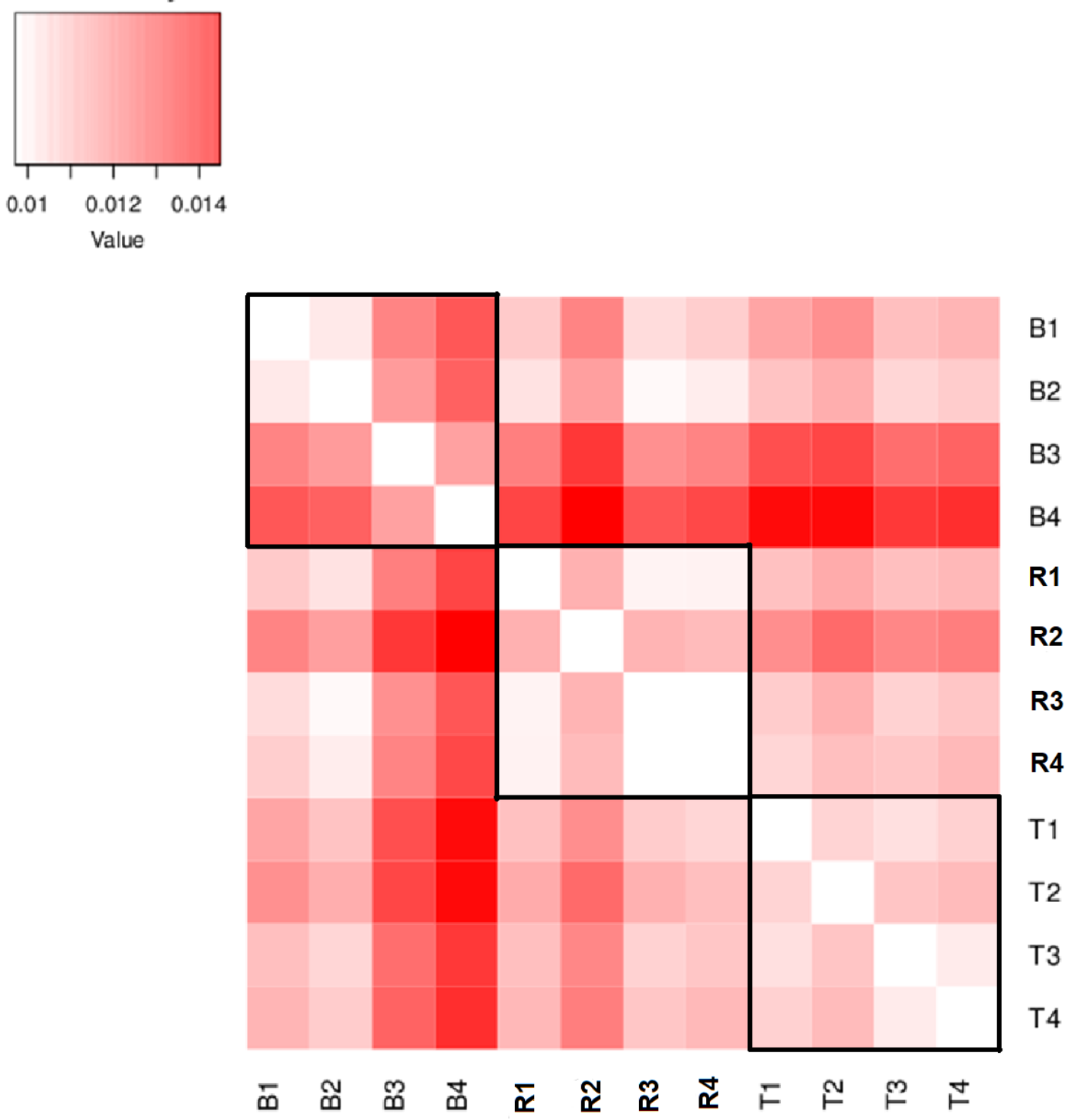
Figure 3. Temporal covariances of allelic frequency changes between different time periods and occurrences of extreme climatic events since the Little Ice Age. Mean and 95\% confidence intervals of the covariance were obtained by bootstrapping with 5000 iterations.

(A) Temporal covariances of allelic frequency changes between 1680-1850 and 1850-1960 in the three forests.

(B) Temporal covariances of allelic frequency changes between 1850-1960 and 1960-2008 in the three forests.

(C) Temporal covariances of allelic frequency changes between 1680-1850 and 1960-2008 in the three forests..

(D) Timeline subdivided in decades. On the right side of the timeline in blue bars, number of extreme winters per decade according to instrumental temperatures recorded at the Observatory of Paris between 1676 and 2010 (Rousseau 2012) (More details in Figure S22). On the left side of the timeline in red bars, number of extreme summer droughts per decade according to Cook's data base of Old World megadroughts (Palmer 1965; van der Schrier et al. 2013; Cook et al. 2015) (for more details Figure S3). Highlighted decades in yellow correspond to periods when the cohorts became installed after natural regeneration. 


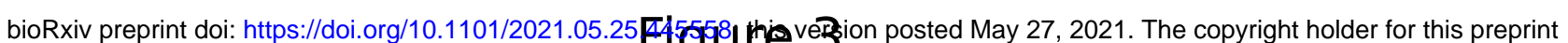

(which was not certified by peer review) is the author/fuhde Un wo has ganted bioRxiv a license to display the preprint in perpetuity. It is

(D)
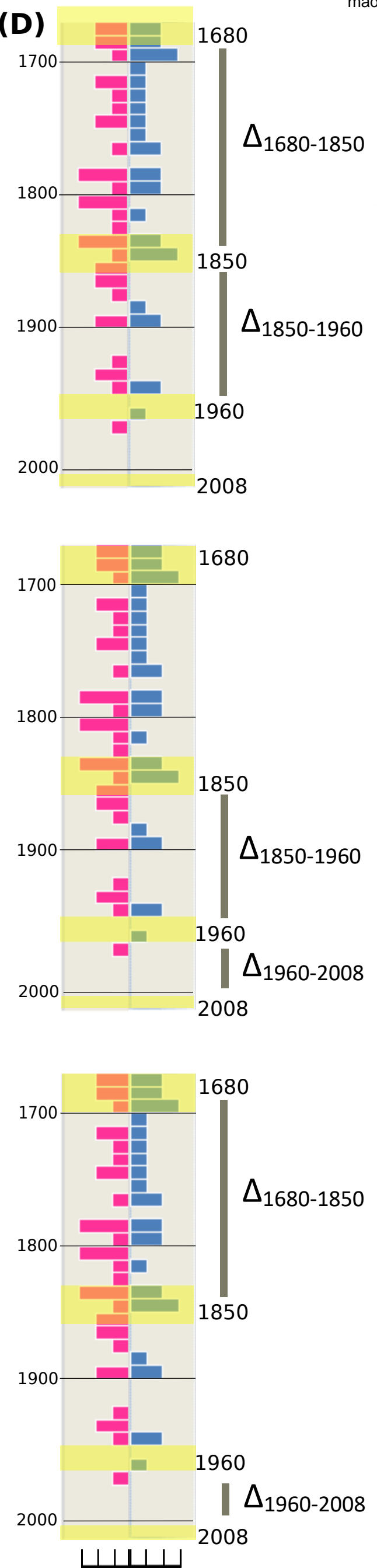

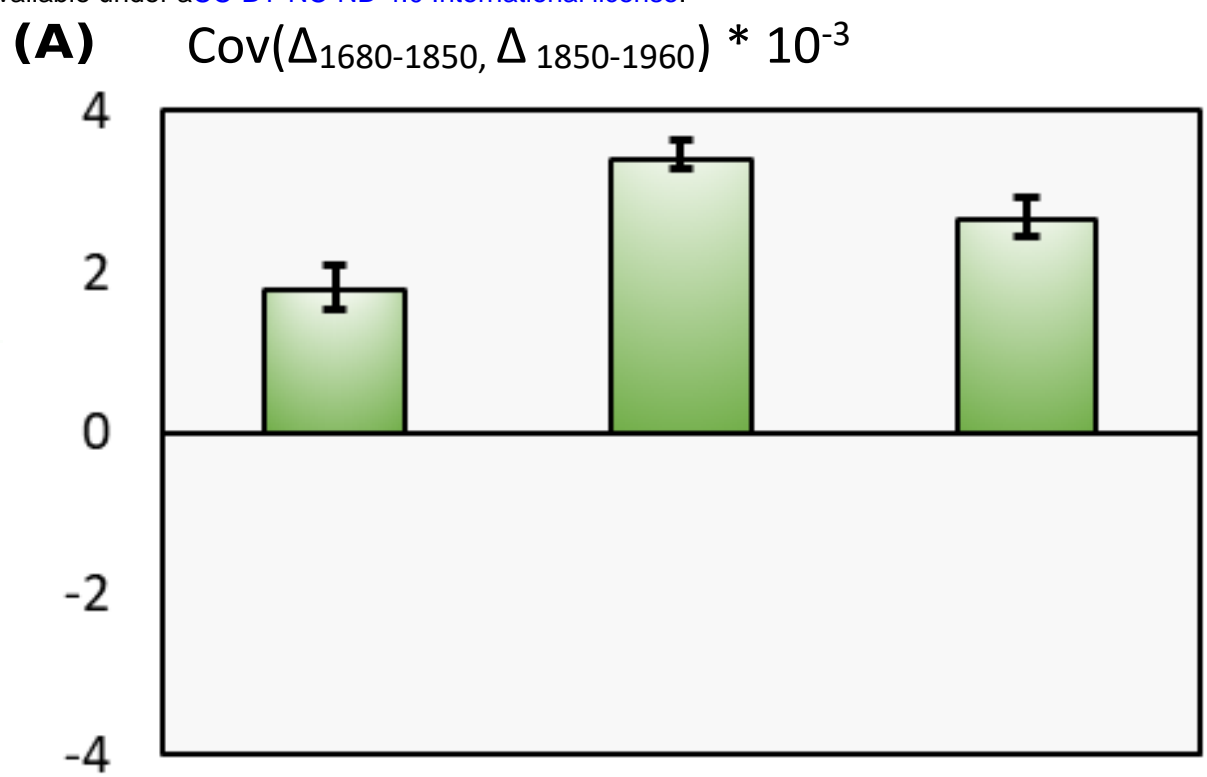

\section{Bercé Réno-Valdieu Tronçais}

(B) $\operatorname{Cov}\left(\Delta_{1850-1960,} \Delta_{1960-2008}\right) * 10^{-3}$

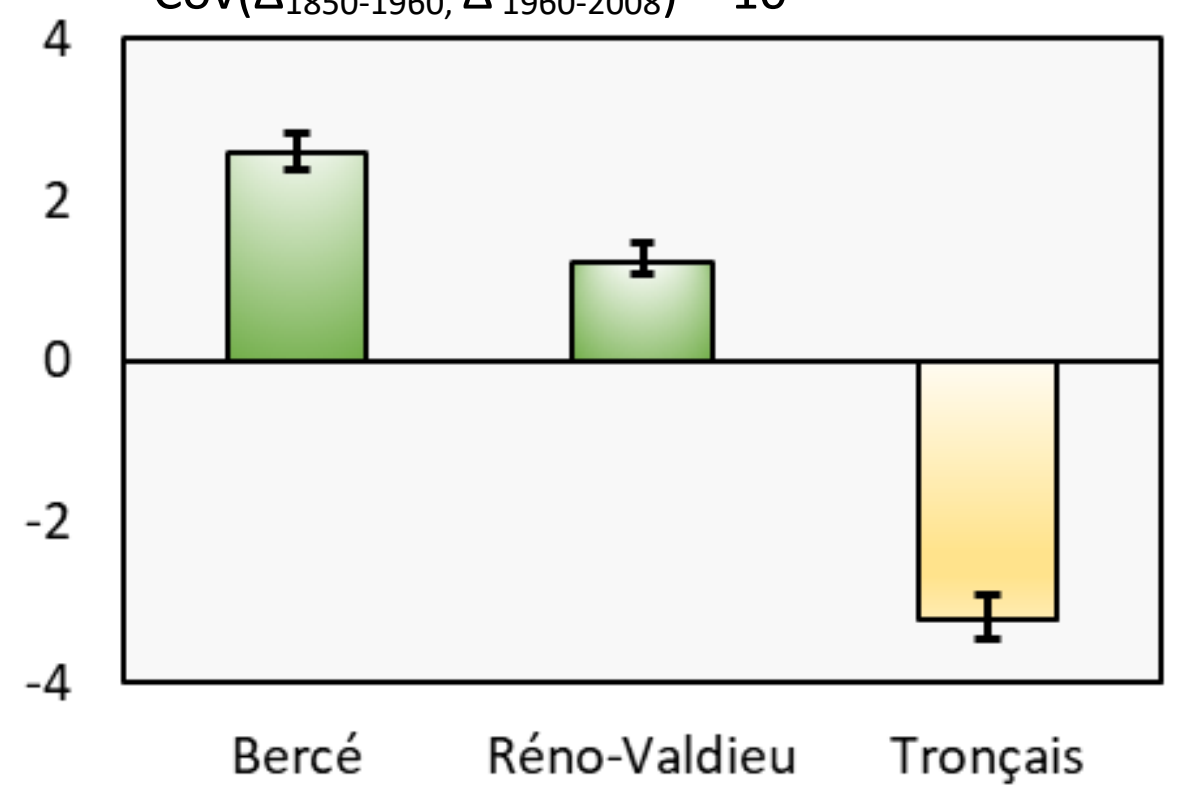

(C)

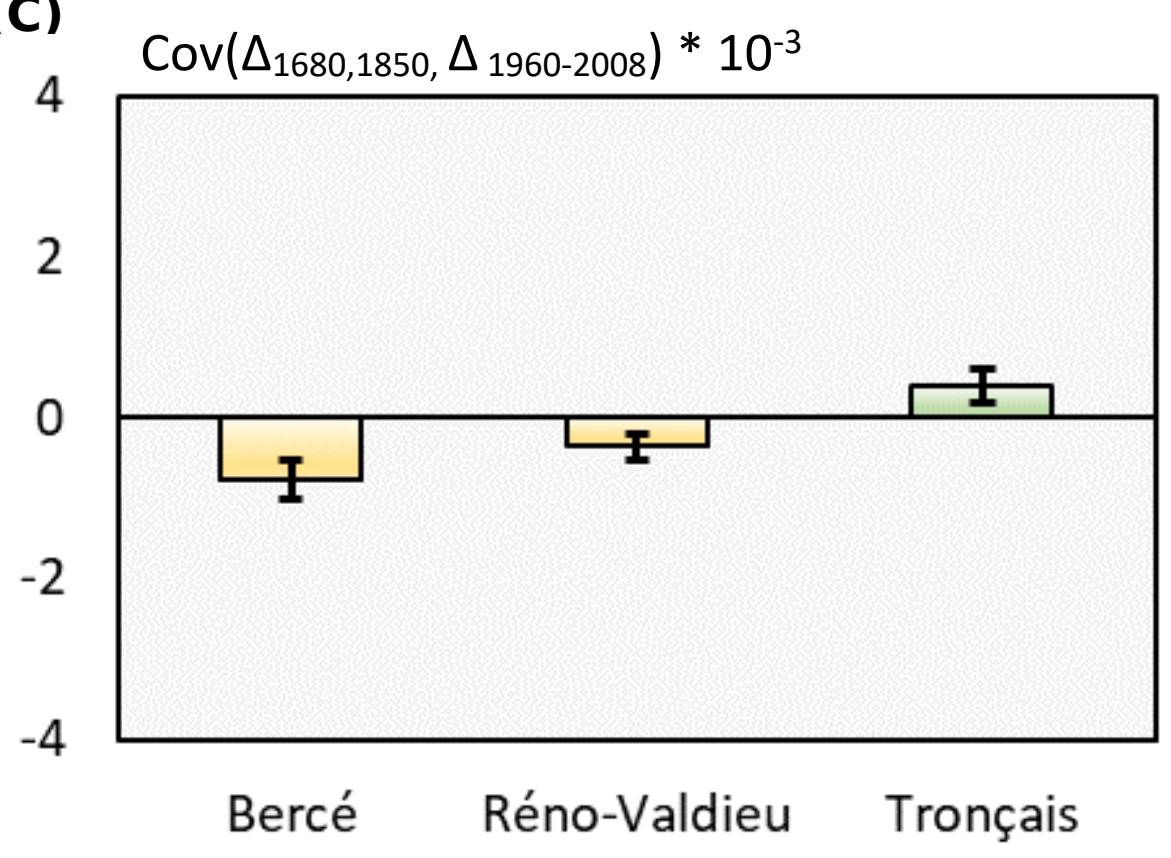

\section{Number of Number of extreme extreme} summers 
Figure 4. Temporal covariances of allelic frequency changes between the different forests for different time periods. Mean and 95\% confidence intervals of the covariances were obtained by bootstrapping with 5000 iterations. Colours of the arrows on the left diagram indicate the time periods considered in the graphs. B : Bercé, R : Réno-Valdieu, T: Tronçais.

(A) Temporal covariances of allelic frequency changes between forests for contemporary time periods.

(B) Temporal covariances of allelic frequency changes between forests for adjacent time periods.

(C) Temporal covariances of allelic frequency changes between forests for distant time periods. 
Forest $X$ Forest $Y$

16801680

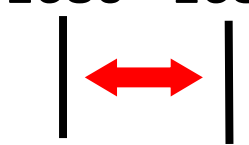

18501850

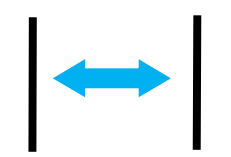

19601960

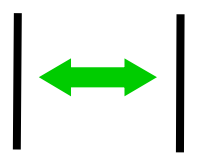

$2008 \quad 2008$

(B)

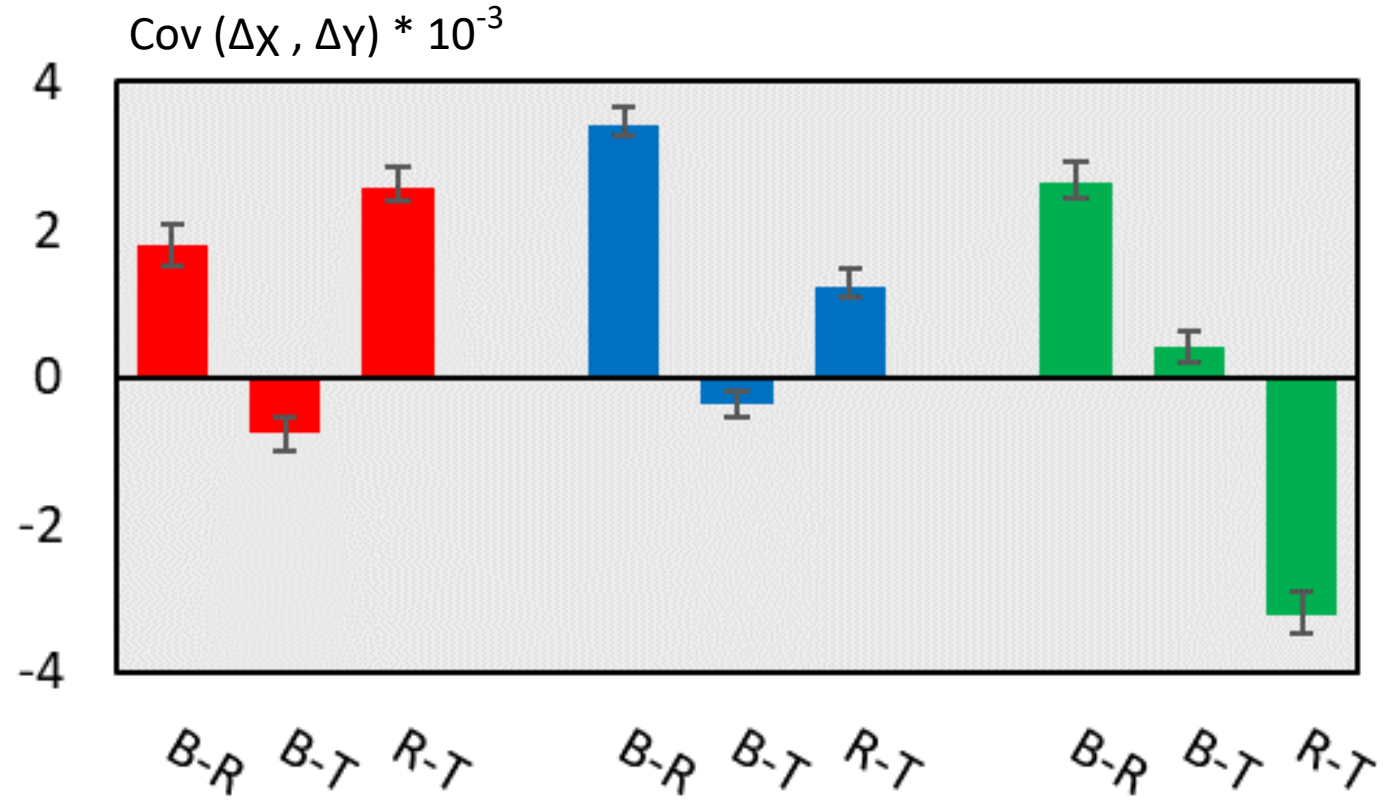

Forest $X$ Forest $Y$ $\operatorname{Cov}(\Delta \mathrm{X}, \Delta \mathrm{Y}) * 10^{-3}$

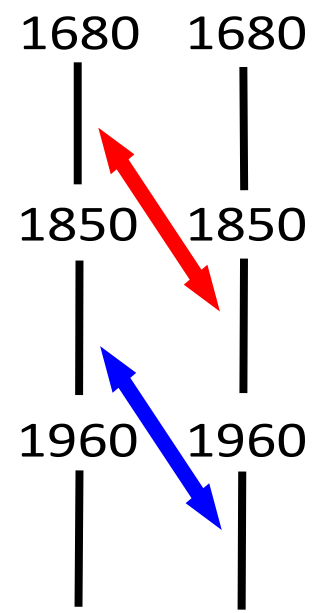

$2008 \quad 2008$

(C)

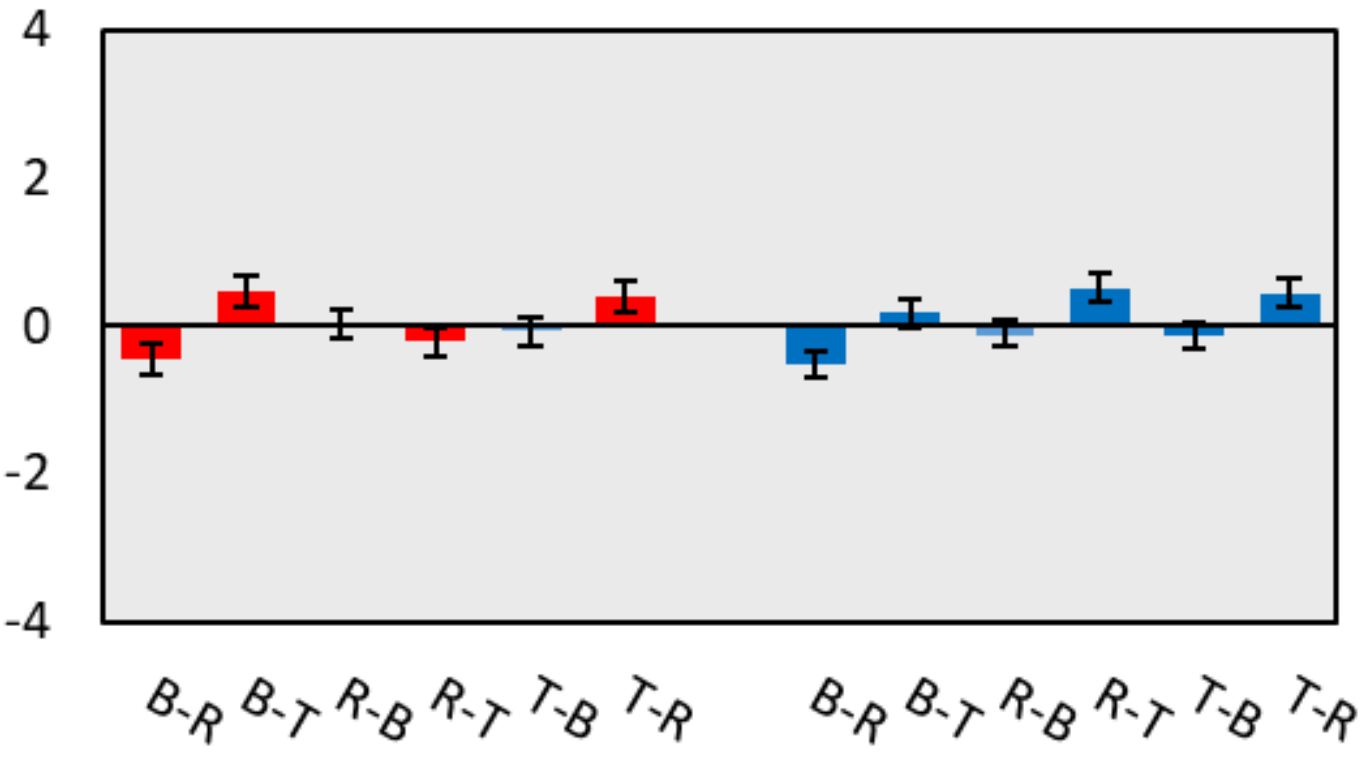

Forest $\mathrm{X}$ Forest $\mathrm{Y}$

16801680

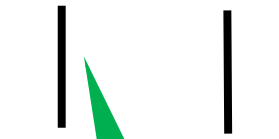

$1850 \quad 1850$

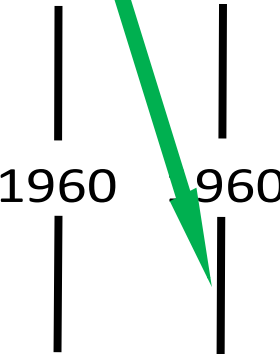

20082008

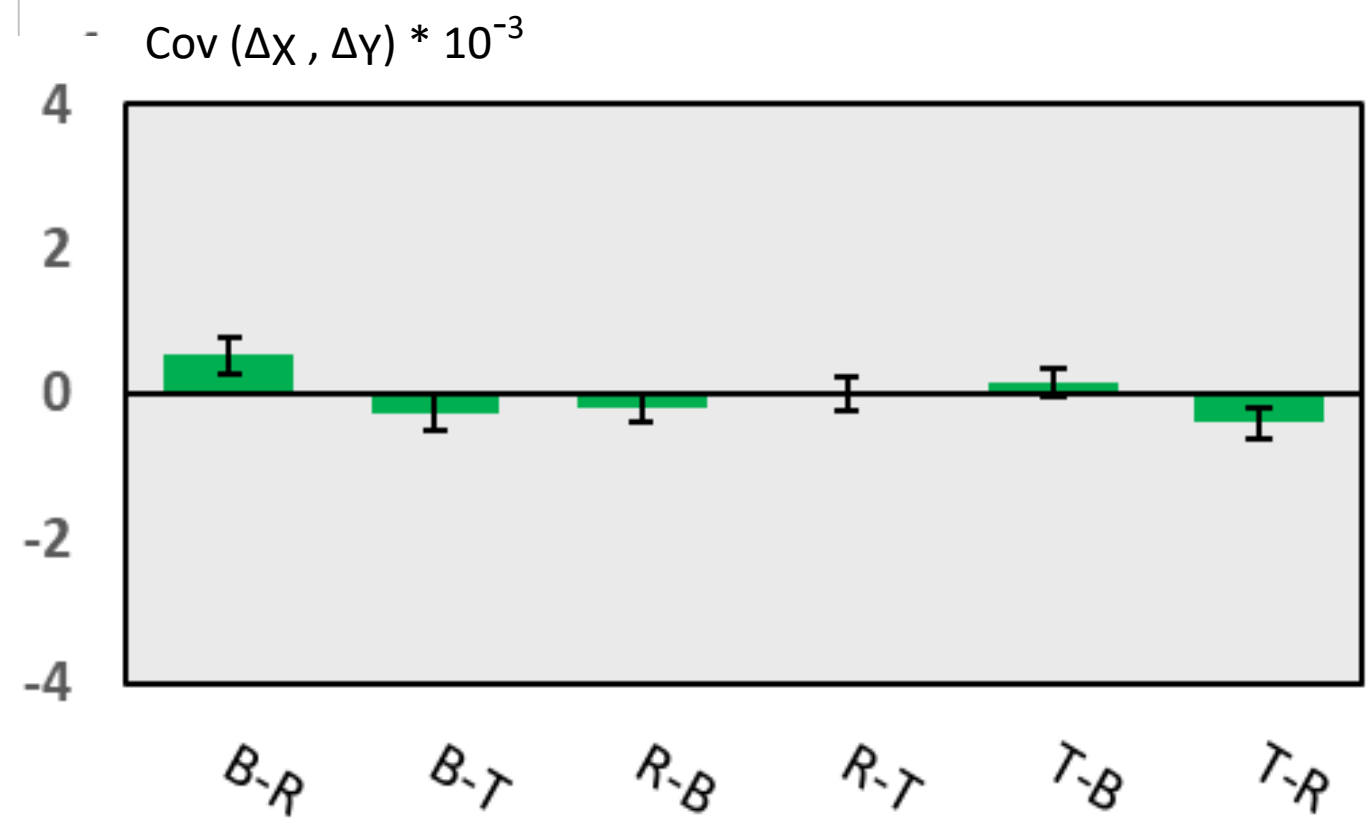


Figure 5. Network plot of the ten most significant Biological Process (BP terms from gene ontology enrichment analysis).

The size of the nodes is proportional to their degree of connectivity. The labels correspond to the name of the Quercus robur gene model followed by the locus name of the best Arabidopsis homolog and the corresponding Arabidopsis gene name (from TAIR: https://www.arabidopsis.org/) between brackets when available. When no gene name exists, a short description (from TAIR or EggNOG databases) is added. If no description is available, the description is set to "unknown". 
bioRxiv preprint doi: https://doi.org/10.1101/2021.05.25.445558; this version posted May 27, 2021. The copyright holder for this preprint (which was not certified by peer review) is the author/funder, who has granted bioRxiv a license to display the preprint in perpetuity. It is made available under aCC-BY-NC-ND 4.0 International license.

\section{FIGURE 5}

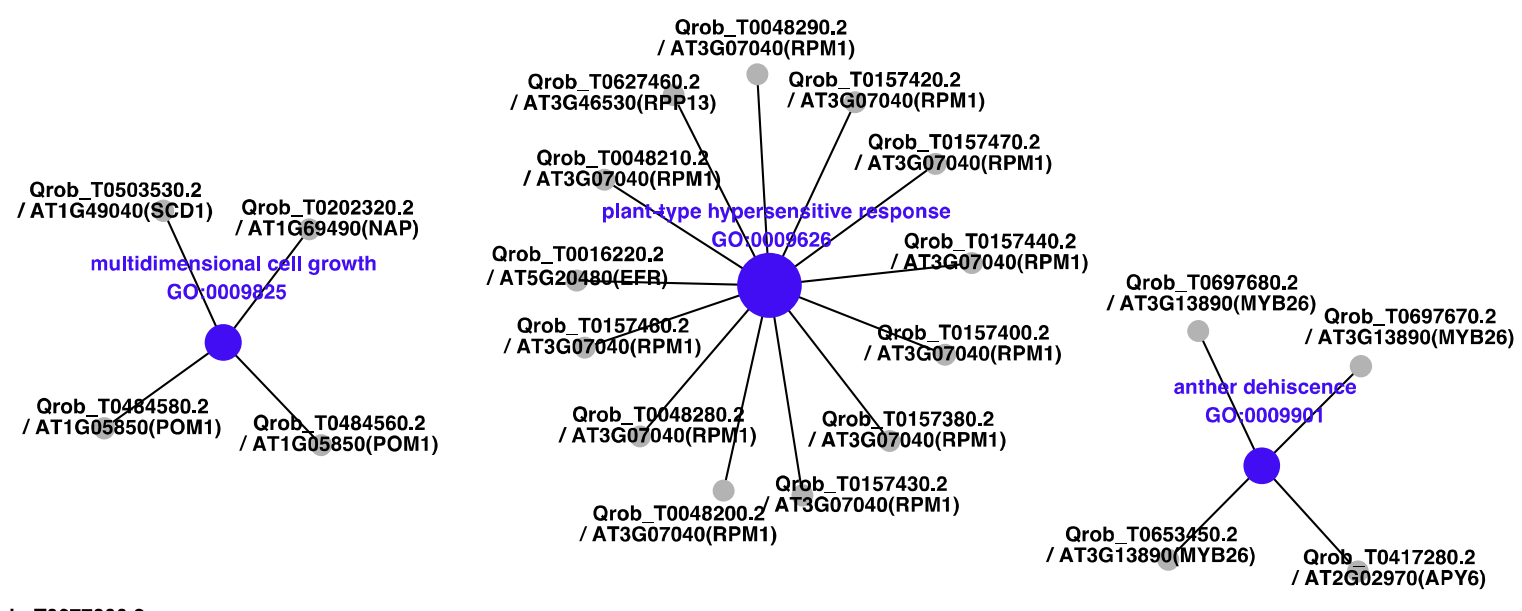

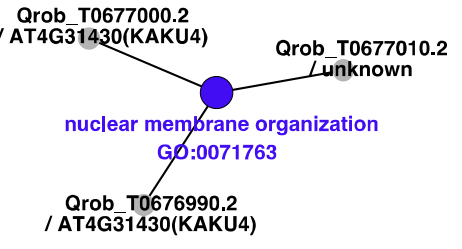

Qrob_T0084540.2

AT2G26250(KCS10)

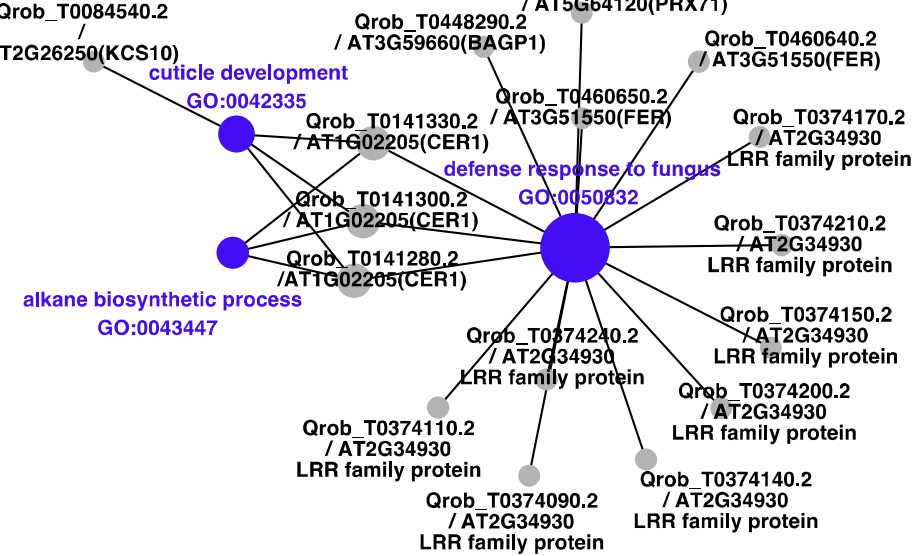

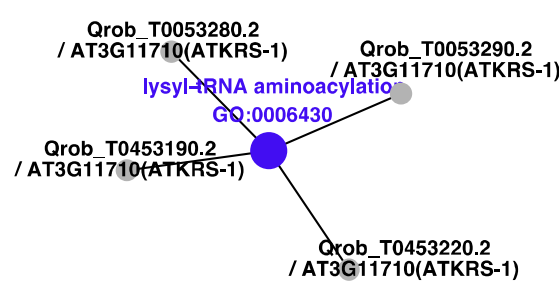

Qrob_T0713370.2
/ AT2G38110(GPAT6)

/ AT2G38110(GPAT6)

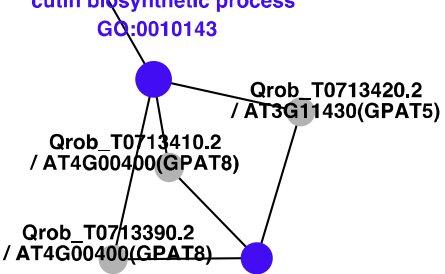

CDP-diacylglycerol biosynthetic process GO:0016024 